Prepared in cooperation with the Bureau de Recherches Géologiques et Minières and the Direction Nationale de la Géologie et des Mines under the auspices of the U.S. Department of State

\title{
Alluvial Diamond Resource Potential and Production Capacity Assessment of Mali
}

Scientific Investigations Report 2010-5044

U.S. Department of the Interior

U.S. Geological Survey 
Cover. View of the Tambaoura Escarpment south of Kenieba, Mali, March 2007. 


\section{Alluvial Diamond Resource Potential and Production Capacity Assessment of Mali}

By Peter G. Chirico, Francis Barthélémy, and Fatiaga Koné

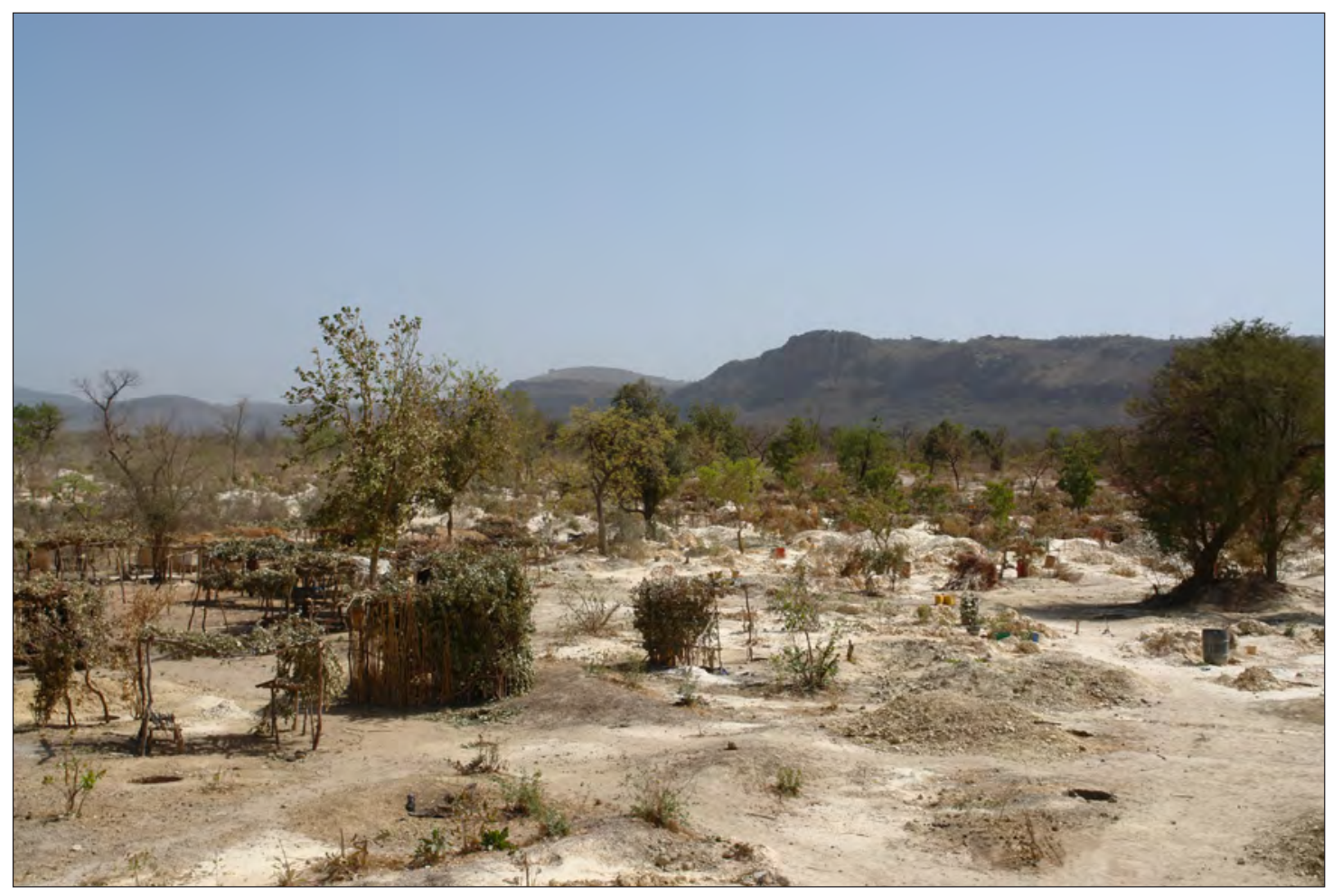

Artisanal gold mining site in Moralia, Mali, February 2007

Prepared in cooperation with the Bureau de Recherches Géologiques et Minières and the Direction Nationale de la Géologie et des Mines under the auspices of the U.S. Department of State

Scientific Investigations Report 2010-5044 


\title{
U.S. Department of the Interior \\ KEN SALAZAR, Secretary \\ U.S. Geological Survey \\ Marcia K. McNutt, Director
}

\section{U.S. Geological Survey, Reston, Virginia: 2010}

\author{
For more information on the USGS — the Federal source for science about the Earth, its natural and living resources, \\ natural hazards, and the environment, visit http://Www.usgs.gov or call 1-888-ASK-USGS \\ For an overview of USGS information products, including maps, imagery, and publications, \\ visit http://www.usgs.gov/pubprod \\ To order this and other USGS information products, visit http://store.usgs.gov
}

Any use of trade, product, or firm names is for descriptive purposes only and does not imply endorsement by the U.S. Government.

Although this report is in the public domain, permission must be secured from the individual copyright owners to reproduce any copyrighted materials contained within this report.

Suggested citation:

Chirico, P.G., Barthélémy, Francis, and Koné, Fatiaga, 2010, Alluvial diamond resource potential and production capacity assessment of Mali: U.S. Geological Survey Scientific Investigations Report 2010-5044, 23 p. (available only online at $h t t p: / / p u b s . u s g s . g o v / s i r / 2010 / 5044 /$ 


\section{Contents}

Abstract

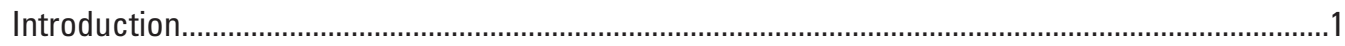

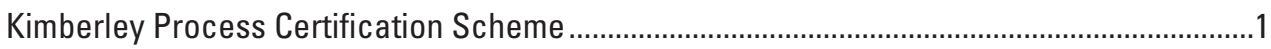

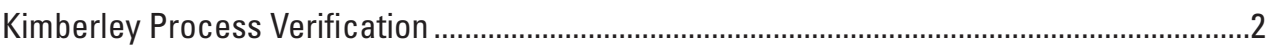

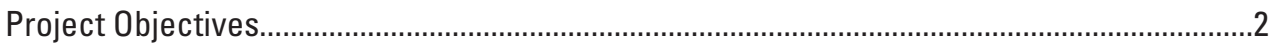

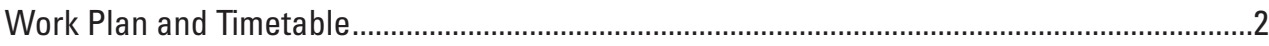

Phase 1: Research ......................................................................................................

Phase 2: Field Evaluation ................................................................................................

Phase 3: Report Preparation .............................................................................................

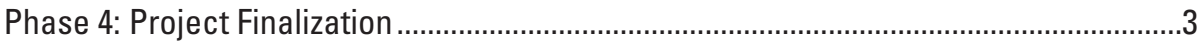

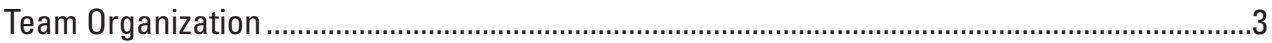

Basic Geologic Description of the Kenieba and Bougouni Mining Regions .....................................

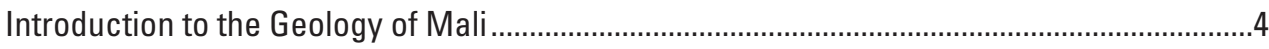

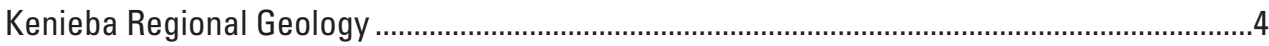

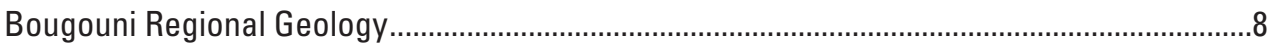

Primary Diamond Occurrences ..............................................................................

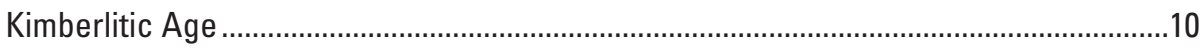

Surficial Morphology of the Kimberlites ....................................................................10

Alluvial Diamond Deposits...............................................................................................

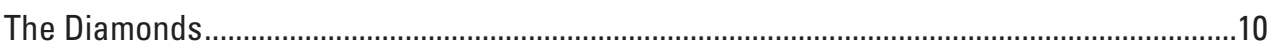

Methodology for Assessing Mali Diamond Resource Potential ...................................................11

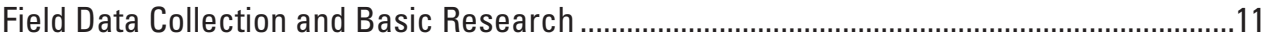

Surveyed Zones and Mining Activity...................................................................................

Assessments of Diamond Potential .......................................................................................12

Cylindrical Calculation of Primary Diamond Deposits .........................................................12

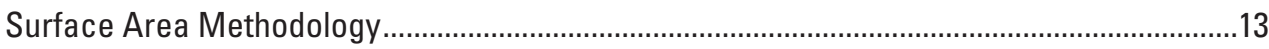

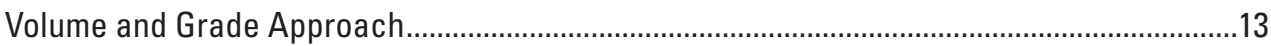

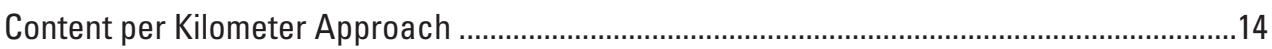

Methodology to Estimate the Capacity of Mali's Diamond Production ..........................................14

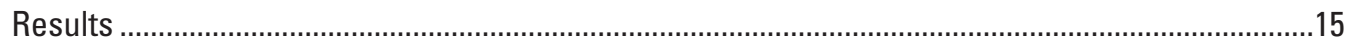

Cylindrical Calculation of Primary Diamond Deposits ........................................................15

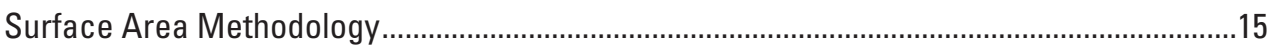

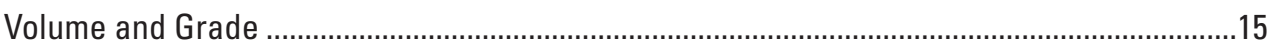

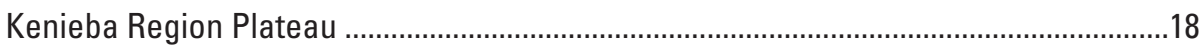

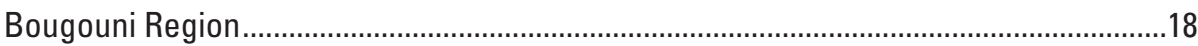

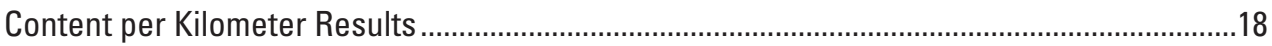

Summary for Kenieba and Bougouni Diamond Potential.......................................................18

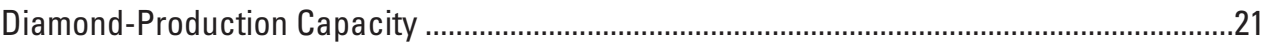

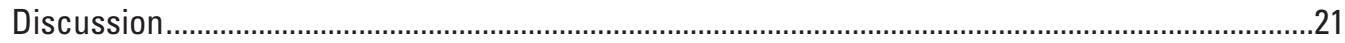

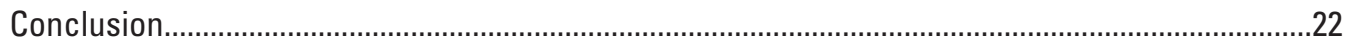

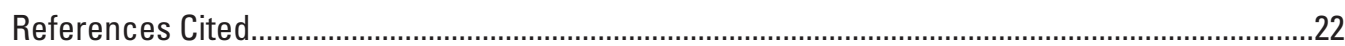




\section{Figures}

1-4. Maps showing-

1. Generalized geology of Mali .5

2. The Birimian formations, diamond showings, and kimberlites of Mali....................6

3. Diamondiferous contour zones in the Kenieba region, Mali .......................................

4. Diamondiferous contour zones in the Bougouni region, Mali.....................................8

\section{Tables}

1. Summary of kimberlite pipe discoveries, Mali................................................................

2. Strahler stream order and corresponding alluvial flat widths .......................................13

3. Diamond yield per kilometer of stream length, Mali......................................................14

4. Primary kimberlite diamond resources, Kenieba, Mali ......................................................15

5. Estimate of diamond resources in the Kenieba alluvial plain and Tambaoura Plateau, Mali, by the surface area approach ..........................................16

6. Estimate of alluvial diamond resources, Kenieba plateau, Mali, by the volume and grade approach .....................................................................................16

7. Estimate of alluvial diamond resources, Bougouni region, Mali, by the volume and grade approach.

8. Estimate of alluvial diamond endowment, Kenieba region, Mali, by the content per kilometer approach.

9. Estimate of alluvial diamond endowment, Bougouni region, Mali, by the content per kilometer approach..............................................................................19

10. Summary of inferred and speculative diamond resources, Kenieba region, Mali ..........20

11. Summary of inferred and speculative diamond resources, Bougouni region, Mali........20

\section{Conversion Factors}

\begin{tabular}{lcl}
\hline \multicolumn{1}{c}{ Multiply } & \multicolumn{1}{c}{ by } & \multicolumn{1}{c}{ To obtain } \\
\hline centimeter $(\mathrm{cm})$ & 0.3937 & inch $(\mathrm{in})$. \\
meter $(\mathrm{m})$ & 3.281 & foot $(\mathrm{ft})$ \\
kilometer $(\mathrm{km})$ & 0.6214 & mile $(\mathrm{mi})$ \\
square meter $\left(\mathrm{m}^{2}\right)$ & 0.0002471 & acre \\
hectare $(\mathrm{ha})$ & 2.471 & acre \\
square kilometer $\left(\mathrm{km}^{2}\right)$ & 247.1 & acre \\
cubic meter $\left(\mathrm{m}^{3}\right)$ & 35.31 & cubic foot $\left(\mathrm{ft}^{3}\right)$ \\
\hline
\end{tabular}




\title{
Alluvial Diamond Resource Potential and Production Capacity Assessment of Mali
}

\author{
By Peter G. Chirico, ${ }^{1}$ Francis Barthélémy, ${ }^{2}$ and Fatiaga Koné ${ }^{3}$
}

\section{Abstract}

In May of 2000, a meeting was convened in Kimberley, South Africa, and attended by representatives of the diamond industry and leaders of African governments to develop a certification process intended to assure that rough, exported diamonds were free of conflictual concerns. This meeting was supported later in 2000 by the United Nations in a resolution adopted by the General Assembly. By 2002, the Kimberley Process Certification Scheme (KPCS) was ratified and signed by diamond-producing and diamond-importing countries.

Over 70 countries were included as members of the KPCS at the end of 2007.

To prevent trade in "conflict diamonds" while protecting legitimate trade, the KPCS requires that each country set up an internal system of controls to prevent conflict diamonds from entering any imported or exported shipments of rough diamonds. Every diamond or diamond shipment must be accompanied by a Kimberley Process (KP) certificate and be contained in tamper-proof packaging.

The objective of this study was (1) to assess the naturally occurring endowment of diamonds in Mali (potential resources) based on geological evidence, previous studies, and recent field data and (2) to assess the diamond-production capacity and measure the intensity of mining activity. Several possible methods can be used to estimate the potential diamond resource. However, because there is generally a lack of sufficient and consistent data recording all diamond mining in Mali and because time to conduct fieldwork and accessibility to the diamond mining areas are limited, four different methodologies were used: the cylindrical calculation of the primary kimberlitic deposits, the surface area methodology, the volume and grade approach, and the content per kilometer approach.

Approximately 700,000 carats are estimated to be in the alluvial deposits of the Kenieba region, with 540,000 carats calculated to lie within the concentration grade deposits.

\footnotetext{
${ }^{1}$ U.S. Geological Survey, Reston, Virginia.

${ }^{2}$ Bureau de Recherches Géologiques et Minières, France.

${ }^{3}$ Direction Nationale de la Géologie et des Mines, Mali.
}

Additionally, 580,000 carats are estimated to have been released from the primary kimberlites in the region. Therefore, the total estimated diamond resources in the Kenieba region are thought to be nearly 1,300,000 carats. The Bougouni zones are estimated to have 1,000,000 carats with more than half, 630,000 carats, contained in concentrated deposits. When combined, the Kenieba and Bougouni regions of Mali are estimated to be host to 2,300,000 carats of diamonds.

\section{Introduction}

\section{Kimberley Process Certification Scheme}

During the late 1990s the issue of "conflict diamonds," or "blood diamonds," became increasingly recognized by the global community, largely due to civil unrest and wars in Sierra Leone and in Angola. In 2001, the United Nations imposed sanctions against the Liberian diamond trade after it accused Liberian President Charles Taylor of supplying weapons and training in exchange for diamonds from the Revolutionary United Front (RUF), which was engaged in a civil war with the government of Sierra Leone. The Democratic Republic of the Congo (DRC) also experienced several civil uprisings during the 1990s, and diamonds were reportedly used to fund rebel forces (Le Billon, 2008).

In May of 2000, a meeting was convened in Kimberley, South Africa, and attended by representatives of the diamond industry and leaders of African governments to develop a certification process intended to assure that rough, exported diamonds were free of conflictual concerns. This meeting was supported later in 2000 by the United Nations in a resolution adopted by the General Assembly. By 2002, the Kimberley Process Certification Scheme (KPCS) was ratified and signed by diamond-producing and diamond-importing countries. Over 70 countries were included as members of the KPCS at the end of 2007.

The KPCS is an international activity whose goal is to prevent trade in conflict diamonds while helping to protect legitimate trade through monitoring of the production, exportation, and importation of rough diamonds throughout 
the world. To accomplish this task, the KPCS requires that each country set up an internal system of controls to prevent conflict diamonds from entering any imported or exported shipments of rough diamonds. Every diamond or diamond shipment must be accompanied by a Kimberley Process (KP) certificate and be contained in tamper-proof packaging. The certificate includes an export origin section, an import verification section, and a security slip. The KP also requires that no diamonds be imported from or exported to a nonmember of the KPCS. Additionally, a recommendation of the KPCS is that all artisanal miners and buyers within a country should be licensed by the host government (Olsson, 2006).

Member countries are required to report their official amount of diamond imports and exports, as well as the value of the diamonds each year to the KP. These data are then made public and provided to other organizations in order to monitor the official statistics reported by all KP members.

\section{Kimberley Process Verification}

It is often difficult to obtain independent verification of diamond-production statistics provided by KPCS member countries. However, some degree of independent verification can be obtained by combining an understanding of the naturally occurring endowment of diamond resources with the country's diamond-production capacity or intensity of mining activity. Studies integrating these two components can produce an estimated range of production values for a country that can then be compared with the actual reported production statistics. Reported production statistics that fall far outside the estimated possible production values may be further investigated to ensure that infiltration of conflict diamonds from an outside source is not occurring.

Recently, the Bureau de Recherches Géologiques et Minières (BRGM) produced an assessment for the Republic of the Congo (Congo Brazzaville) (Barthélémy and others, 2006). This assessment was acclaimed within the KPCS community as a method for independent verification of alluvial diamond resources. A similar assessment was also conducted by the U.S. Geological Survey (USGS) in Liberia (Wahl and others, 2007). The USGS assessment made substantial contributions to the assessment process of the diamond potential and contributed to a lifting of the sanctions on mining and selling of diamonds imposed on Liberia through the Kimberley Process.

The work of both the BRGM and the USGS in this field continues as the organizations have partnered to conduct independent evaluations of the diamond potential in Mali and the Central African Republic.

\section{Project Objectives}

There are six main objectives of this current project:

1. Produce a synthesis of geological and alluvial (placer) diamond-production information for Mali from historical documentation.

2. Develop a model to estimate the endowment of undiscovered diamond resources in Mali.

3. Use the model to estimate Mali's production capacity for rough diamonds.

4. Create a detailed geographic information system (GIS) of diamond mining.

5. Transfer to Mali the GIS to provide information resources to monitor diamond mining areas.

6. Develop and conduct a workshop to present the final report results in conjunction with the Direction Nationale de la Géologie et des Mines (DNGM).

\section{Work Plan and Timetable}

The Mali evaluation was completed in four phases: research, field evaluation, initial report preparation, and project finalization. The entire process occurred over approximately a year and a half.

\section{Phase 1: Research}

Phase 1 of this study included research, collection, and organization of all available data related to diamond resources and production in Mali. This endeavor required a significant bibliographic study and the collection of geologic maps, geophysical data, and remotely sensed satellite imagery. During this phase, basic evaluations of the incoming data were conducted to assess its relevance, quality, and importance for diamond assessments.

Reports were examined to find all documented occurrences of diamonds, alluvial gold, and, where possible, the resource grade recorded at these locations. A digital database of diamond occurrences and grades was compiled to include geographic coordinate information. This database was then mapped to display the spatial distribution of diamond occurrences based on historical field surveys. Phase 1 was completed over the course of 4 months. 


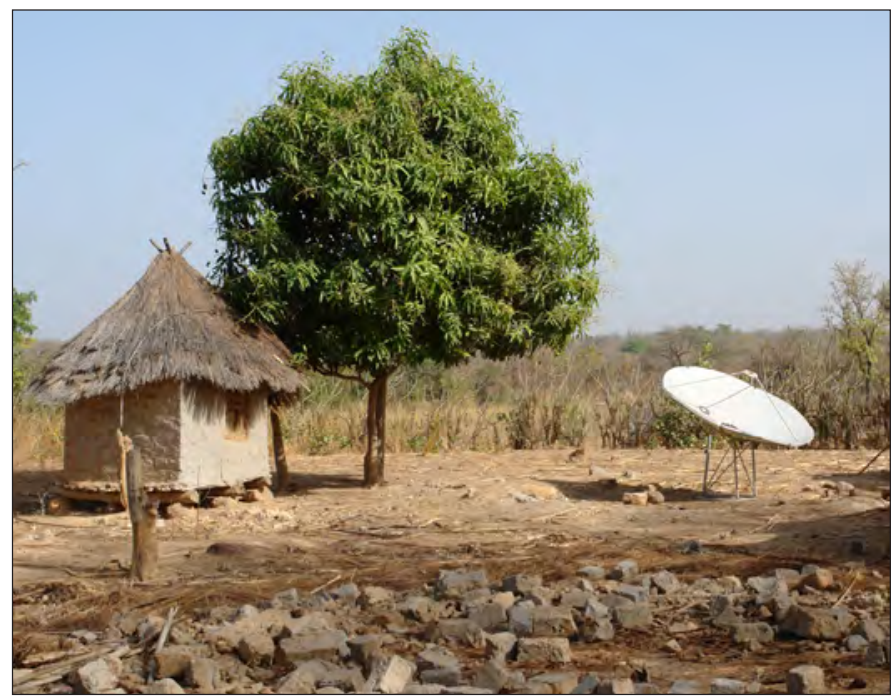

Typical village hut near Kenieba, Mali

\section{Phase 3: Report Preparation}

Phase 3 incorporated the preparation of the resource assessments and the production capacity estimates. All field data were compiled, organized digitally, and analyzed. The GIS databases were developed using both the data gained from the historical research and the field surveys from phase 2. Once the compilation and analysis of the data and the GIS database were complete, the final report was written. Phase 3 was completed over the course of 7 months.

\section{Phase 4: Project Finalization}

The final phase of the project was the presentation and final discussions of the project report. An in-country workshop was organized to include both practical fieldwork-oriented trainings and discussions of the project report among the team members. After the workshop and training were completed, the reports were finalized to reflect the discussions and recommendations of the team members and delivered to all parties involved. Phase 4 was completed over the course of 4 months.

\section{Phase 2: Field Evaluation}

The second phase of this project was field evaluation. This phase incorporated all aspects of the planning and execution of on-the-ground field studies and field data collection in the diamond mining areas of Mali. Also included was time spent developing contacts and working with the scientists and staff of the DNGM in Bamako.

Two field excursions were completed under the scope of this study. The first was composed of project members representing the USGS, the BRGM, and the DNGM and occurred in February 2007. The second field excursion occurred in April 2007 and was composed of project members from the BRGM and the DNGM.

The fieldwork component of the project identified and characterized the mining regions of Kenieba and Bougouni. Fieldwork was conducted in both regions. The first field excursion to the Kenieba region included 10 project scientists. The teams of two or four project scientists visited kimberlite areas and alluvial gold workings. During the Kenieba region fieldwork, two teams conducted global positioning system (GPS) mapping of roads and infrastructure and collected ground control points for the geometric correction of satellite imagery.

In April 2007 a joint DNGM-BRGM team visited the Bougouni alluvial gold mining region and collected field data at alluvial gold mine sites. The main goals of the field excursions were to characterize the mining areas, evaluate current artisanal mines, gather data concerning diamond discoveries, and collect field data. Phase 2 was completed over the course of approximately 3 months.

\section{Team Organization}

This project was supported by the Economic Support Fund (ESF) provided by the U.S. Department of State and was executed by a trilateral partnership of scientists and technical professionals from the USGS, the BRGM, and the DNGM of Mali.

Peter G. Chirico, USGS, Project Chief, Geographer Omayra Bermudez-Lugo, USGS, Minerals Economist Emily Phillips, USGS, Researcher

Michael Warner, USGS, GIS/Remote Sensing Analyst François M.J. Lampietti, USGS, Consulting Economic Geologist

Francis Barthélémy, BRGM, Geologist

Yves Husson, BRGM, Geologist

Waly Diawara, DNGM, Directeur Nationale Adjoint, Ingénieur Economiste Minier

Fatiaga Koné, DNGM, Chief Division Géologie

Bourema Djiguiba, DNGM, Geographic Information Specialist

Yaya Djire, DNGM, Mining Engineer 


\section{Basic Geologic Description of the Kenieba and Bougouni Mining Regions}

\section{Introduction to the Geology of Mali}

Mali is located on the northeasternmost part of the West African Craton and the Turareg shield. The shields were joined during the Neoproterozoic Pan-African orogeny. The West African cratonic rocks crop out in western Mali along the border with Senegal and the Falémé River. The Turareg Shield crops out in the eastern part of Mali in the Adrar des Iforas Mountains.

The West African cratonic rocks consist of the Reguibat Shield, which extends to the northern boundary of Mali, and the Leo or Man Shield, which extends to the south. The Leo Shield is composed of Archean rocks and the Birimian Sandstone, which are Early and Middle Proterozoic in age. The rocks composing the Leo Shield are mainly graniticgneissic complexes with belts of volcanogenic rocks similar to the Archean greenstone belts (Kusnir, 1999).

The Taoudeni basin covers a large portion of the area between the Reguibat Shield and the Leo Shield. The basin contains significant marine sediments (Schlüter, 2006) of Neoproterozoic to Carboniferous age consisting of sandstone, dolomite, limestone, and siltstone. Additionally, Cretaceous, Paleogene, and Neogene sediments, dunes, and lateritic soils cover parts of much of central and western Mali.

Outcrops of the West African Craton of the Leo Shield occur in two regions in Mali. The first is the Kenieba region, generally located south of the city of Kayes and extending along the western border with Senegal south past the town of Kenieba. The second region of outcrop is Bougouni, which lies south of Bamako along the border with Guinea and Côte d'Ivoire (figs. 1, 2).

\section{Kenieba Regional Geology}

The Kenieba region (see fig. 3), located on the western side of the West African Craton, is underlain by Archean to Lower Proterozoic Birimian (2,300-1,900 mega-annum, Ma) rocks. To the east of Kenieba, the Tambaoura Escarpment rises abruptly nearly 500 meters (m) in elevation. The Tambaoura Escarpment is composed of Upper Cambrian sandstone and lies atop the Birimian rocks. Here the Birimian rocks are composed of slightly metamorphosed schist, greywacke, quartzite, and marble. North of Kenieba, volcanogenic rocks, including andesites and basalts, occur (Arnold, 1991).

The Kenieba region occurs in a triangular-shaped area and is part of the Eburnean domain (2,030-1,830 Ma). This area is represented largely in western Africa and covers the southern part of Mali. It then reoccurs in the KedougouKenieba area and the much smaller area north of Kayes (Bessoles, 1997). This Eburnean domain principally is made up of flysch, volcanics, and granitic-gneissic complexes (Milési and others, 1989).

Rocks in the Kedougou-Kenieba area extend to the Senegalese-Malian border and are represented by Birimian groups of Paleoproterozoic age. The lower group consists of schists and greywacke, argillite and siltite formations with graphite and conglomerate levels, an acidic volcanicsedimentary formation, and a mixed carbonate and acidic volcanic formation. The upper group consists of basaltic and andesitic formations, and rhyodactic formations which are associated with the fluvial-deltaic deposits. The group is intruded by undifferentiated granites corresponding to several phases of the Eburnean cycle. The Lower Proterozoic is overlain by strata of Upper Proterozoic to Paleozoic age of the Taoudeni basin.

Structurally, the Kedougou-Kenieba area is east of the western and southern borders of the West African Craton that marks the boundary of the mobile Mauritanides-Rockellides belt. This belt belongs to the Pan-African domain (600 Ma).

Granitic massifs have intruded the metavolcanics. The Kakadian batholith complex in the northern Kenieba region has been dated at 2,180 and 1,960 Ma (Direction Nationale de la Géologie et des Mines, 1987). Kimberlite pipes intrude both the Birimian and Upper Cambrian sandstones of the Tambaoura Escarpment along with granite batholiths, diorite, gabbro, and doleritic dikes and sills (Arnold, 1991). Michel (1996) has suggested that the kimberlitic magmatism could be Early Cretaceous in age, but he also points to the possibility of multiple events of kimberlitic intrusion. The kimberlites generally are considered Early Proterozoic (1,000 Ma) in age.

The 2,000-year-old artisanal gold mining activity includes both primary deposits, such as the veins of Tabakoto, which have been exploited to a depth of more than $50 \mathrm{~m}$, and ancient and recent alluvial deposits, notably those in the Falémé River. Rocks of the Birimian Sandstone have primary gold mineralization. Also, the alluvial sediments eroding these rocks contain gold mineralization and now form placer deposits along the Falémé River and streams (fig. 2). The primary gold mineralization is related to the quartz veins within the Birimian Sandstone and tourmaline-rich quartzites (Direction Nationale de la Géologie et des Mines, 1987).

The kimberlitic province of Kenieba spans both the Birimian rocks of the Kedougou-Kenieba area and the sandstone plateau of the Tambaoura Escarpment, which is part of the Taoudeni basin. In the western part of the study area, the Falémé valley is composed of Birimian schists, injected with gold-bearing quartz veins and doleritic dikes, and is intruded by several granite batholiths and kimberlite pipes. The schists were affected by the second Eburnean tectono-metamorphic event, which is also responsible for the large north-south to northeast-southwest-trending thrust faults. To the east, this plain is bordered by the Tambaoura Escarpment, which represents Upper Proterozoic sandstone and conglomerate cover over the Birimian rocks; several sandstone outliers remain in the Birimian plain. These sandstones are injected with dikes and dolerite sills forming particularly resistant layers. 


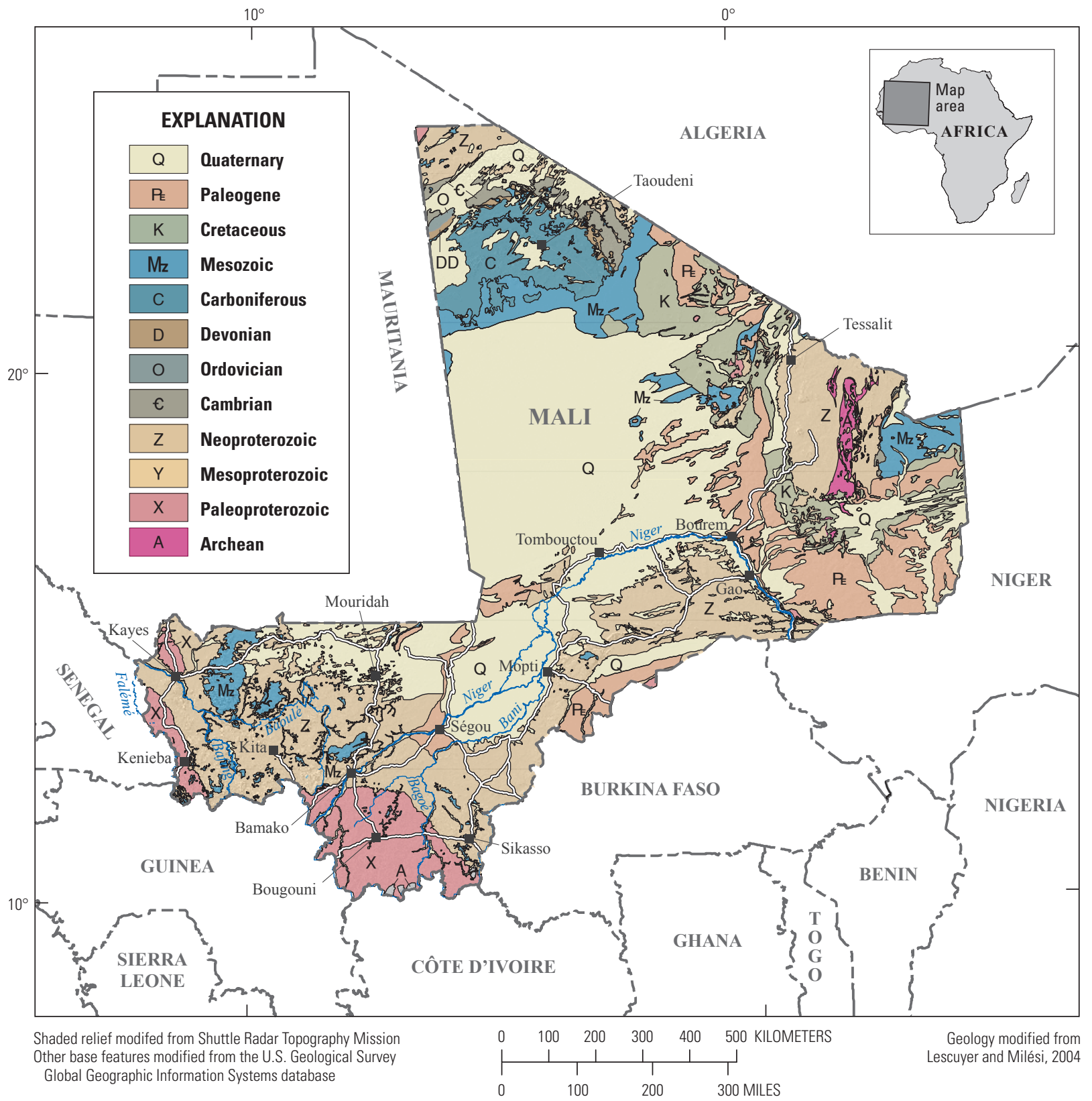

Figure 1. Generalized geologic map of Mali. 


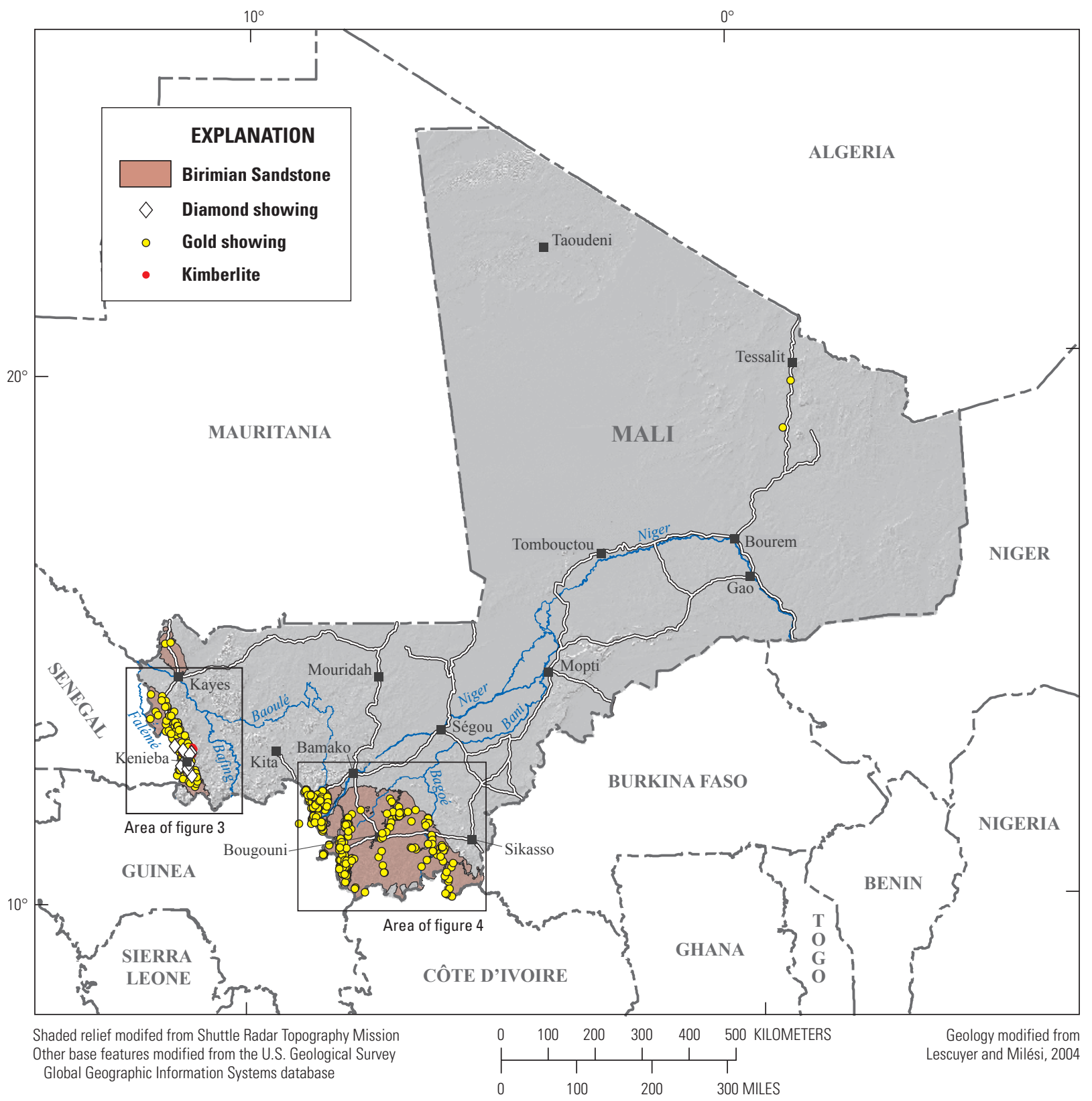

Figure 2. The Birimian formations, diamond showings, and kimberlites of Mali. 


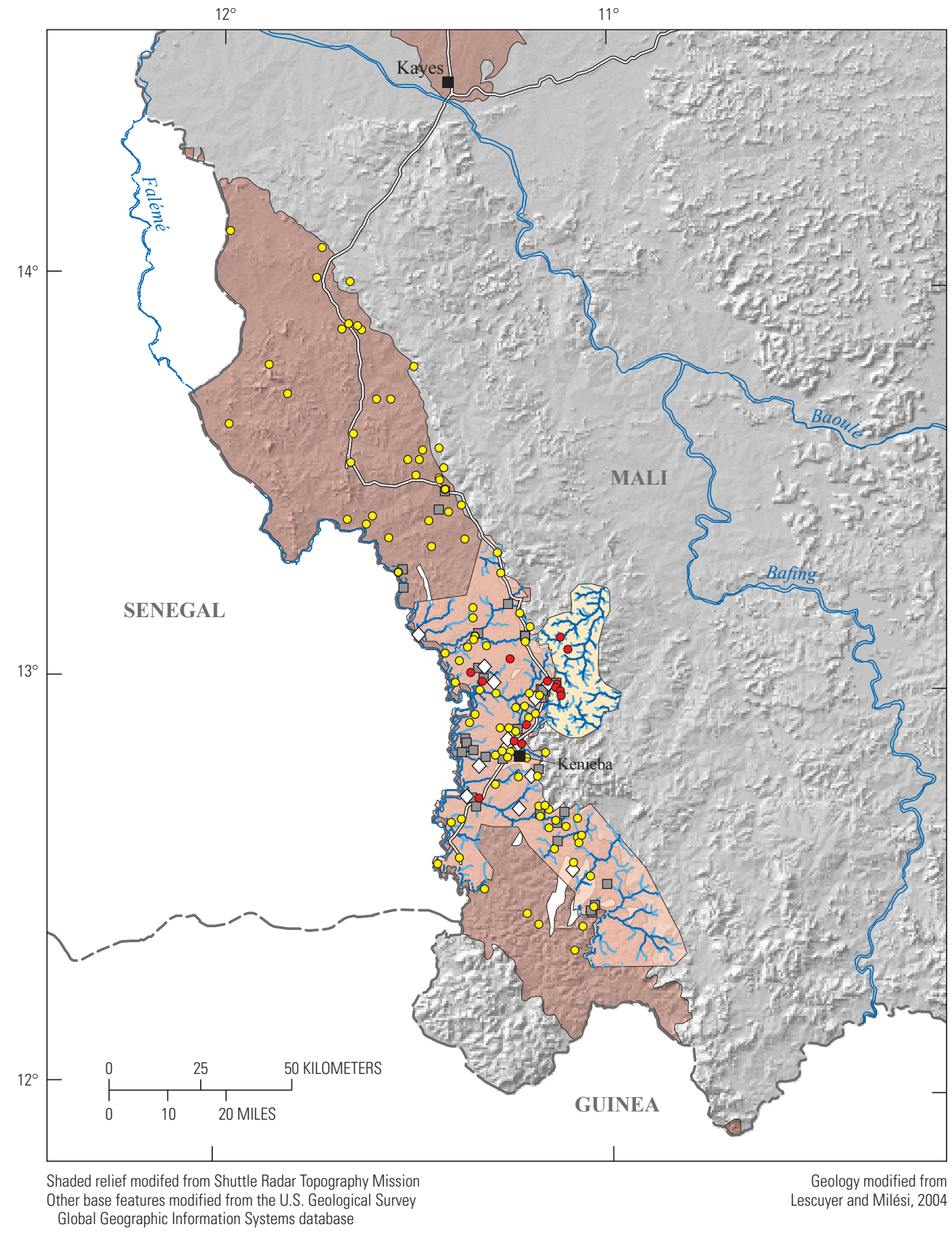

EXPLANATION

\begin{tabular}{lll}
\hline & Birimian Sandstone & $\diamond$ Diamond showing \\
$\square$ Kenieba contour zone & $\circ$ Gold showing \\
$\square$ & $\begin{array}{l}\text { Tambaoura Escarpment } \\
\text { contour zone }\end{array}$ & $\bullet$ Kimberlite \\
$\begin{array}{l}\text { Major stream } \\
\text { Minor stream }\end{array}$ & $\square$ USGS/ BRGM study site \\
\hline
\end{tabular}

Figure 3. Diamondiferous contour zones in the Kenieba region, Mali. 
Lateritic crusts cover much of the landscape. The ferruginous crusts are composed mainly of hematite and goethite nodules and range from 1 to $5 \mathrm{~m}$ thick.

\section{Bougouni Regional Geology}

The underlying geology of the Bougouni region (fig. 4) is dominated by granitic-gneissis and Birimian greenstone belts. Three massifs separate four Birimian belts of rock: the Bagoé, Bougouni-Keikoro, Yanfoliba, and Kangaba. The Bagoé is a synclinorium that forms a basin running along the Bagoé River. The basin is composed of schists and greywackes; metavolcanics flank the edges of the basin.
The Bougouni-Keikoro belt is composed of thermally metomorphosed rocks, but it also contains andesites. The Yanifolia belt is composed of schists and greywackes with minor volcanics and quartzites. The Kangaba belt occurs in the southwesternmost part of Mali, extending into Guinea, and the geology is similar to that of the Yanifolia belt (Direction Nationale de la Géologie et des Mines, 1987).

These four belts are the focus of a number of primary gold and diamond exploration permits. During the course of the project, an exploration program financed by the System of Stabilization of Export Earnings from Mining Products (SYSMIN) carried out subsurface investigations to locate kimberlitic intrusions around Bougouni, which correlated to geophysical anomalies. Data from this work were not used in this study.

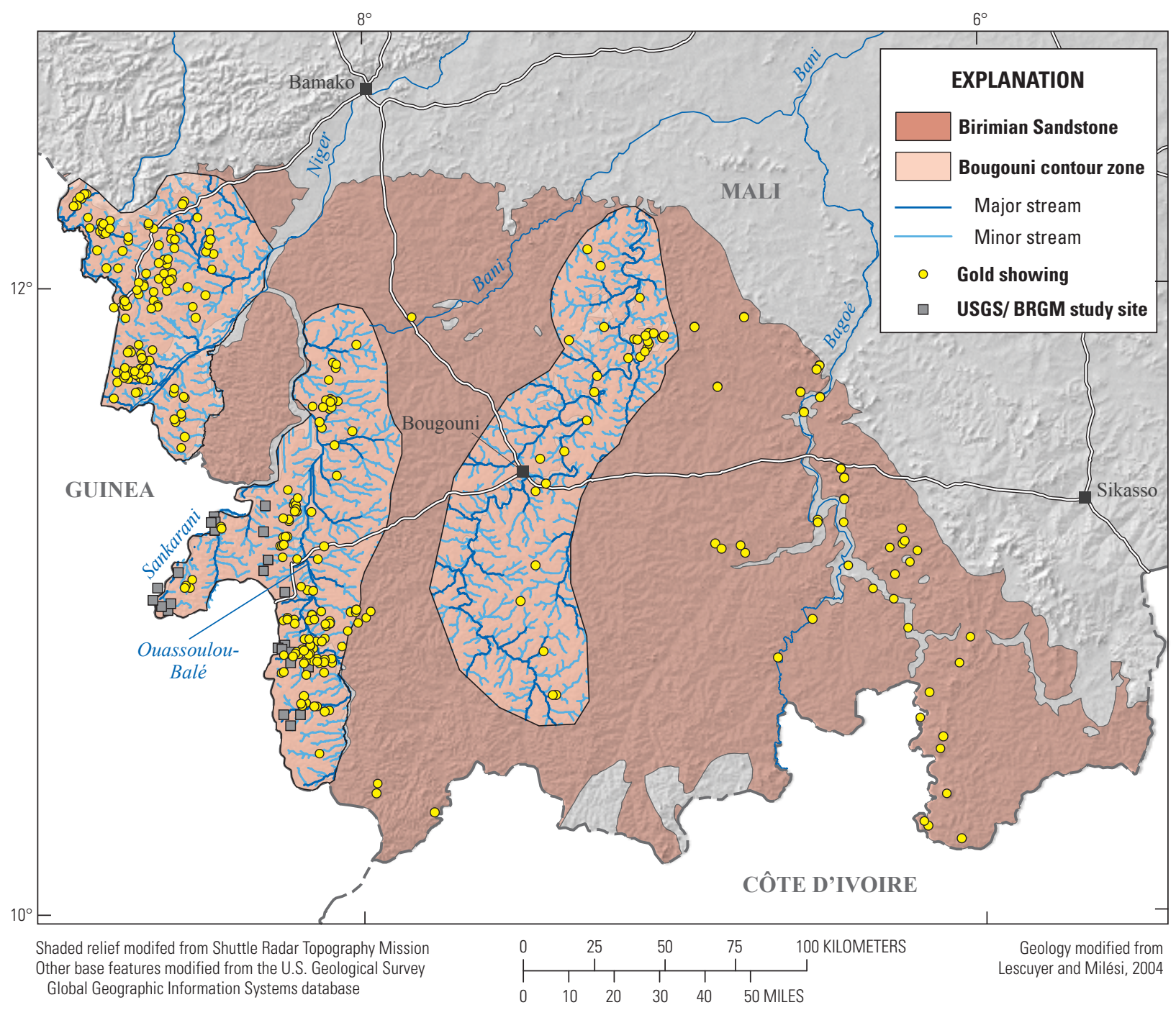

Figure 4. Diamondiferous contour zones in the Bougouni region, Mali. 


\section{Primary Diamond Occurrences}

The Mali kimberlites are restricted to a $30 \times 50$ kilometer $(\mathrm{km})$ sector, forming a relatively tight cluster. They are intrusive in both the Birimian rocks and Upper Proterozoic sandstone, though they occur in much greater abundance in the Birimian plain.

A varying number of kimberlites have been reported in the Kenieba region as a result of explorations beginning after the first diamonds were discovered in 1954. It is commonly reported that 8 of the 29 kimberlites sampled are diamondiferous. Since the first discoveries, many more diamonds have been recovered, the largest of which was 232.7 carats (kt). Table 1 shows a summary of kimberlite pipe occurrences for the Kenieba region in western Mali.
From 1954 when diamonds were first discovered, until 1957, the French Direction Fédérale des Mines et de la Géologie (DFMG) prospected the alluvial deposits of Kenieba. Shortly after, they also began to conduct kimberlitic prospecting. A 98-kt diamond was discovered in the Sansanto placer along the Doundé River. Other diamonds were recovered, including one in the Sekonomata pipe.

From 1963 until 1966, the Selection Trust explored for kimberlites by sampling alluvium and soil. Eight kimberlite pipes were found in Kenieba: Batifara, Mission, Silifoundou, Kenieba, Fanson, Orange River, South Bilali, and Dabora. North and South Cirque, Mission, and South Bilali were found to be diamondiferous. From 1963 to 1966 the Société Nationale de Recherche et d'Exploitation Minière (SONAREM) prospected eastern Mali and Bougouni, Sikasso, and Kenieba in the west.

Table 1. Summary of kimberlite pipe discoveries, Mali.

[BRGM, Bureau de Recherches Géologiques et Minières; DFMG, Direction Fédérale des Mines et de la Géologie (France); MADE, Mali Diamond Exploration; SELCO, Selection Trust Exploration (Great Britain); SONAREM, Société Nationale de Recherche et d'Exploitation Minière; Syndicat, Mali Diamond Syndicate (created by BRGM, Mines et Ressources SA, DFMG); - , unknown]

\begin{tabular}{|c|c|c|c|c|c|c|}
\hline Name & $\begin{array}{l}\text { Surface area } \\
\text { (hectares) }\end{array}$ & $\begin{array}{l}\text { Diameter } \\
\text { (meters) }\end{array}$ & $\begin{array}{l}\text { Number } \\
\text { of stones }\end{array}$ & $\begin{array}{l}\text { Weight } \\
\text { (carats) }\end{array}$ & $\begin{array}{l}\text { Discoverer } \\
\text { of diamond }\end{array}$ & Worked on pipe \\
\hline South Bilali & 4 & - & 6 & 8.79 & SELCO, Syndicat & BRGM, MADE \\
\hline North Cirque & 11 & - & 4 & 8.14 & SELCO & DFMG, SONAREM, BRGM \\
\hline South Cirque & 8.2 & - & 1 & 0.3 & Syndicat & DFMG, SELCO, SONAREM, BRGM \\
\hline Sekonomata & 2 & - & 1 & 0.223 & DFMG & BRGM, MADE, Syndicat \\
\hline Batifara & 4.9 & 250 & 1 & 0.15 & Syndicat & SELCO, MADE \\
\hline Orange River & 5 & - & 1 & 0.05 & Syndicat & SELCO, BRGM \\
\hline Mission & 0.2 & 60 & 1 & 0.05 & SELCO & BRGM \\
\hline Pipe 117 & 10.5 & - & 14 & $\begin{array}{l}\text { micro } \\
\text { diamonds }\end{array}$ & Syndicat & MADE \\
\hline Fougola & 0.25 & - & - & $\begin{array}{l}\text { micro } \\
\text { diamonds }\end{array}$ & - & MADE \\
\hline Kassama & - & - & 0 & 0 & & SELCO, MADE \\
\hline Kereko & - & - & 0 & 0 & & MADE \\
\hline Tenin-Camara & - & - & 0 & 0 & & MADE \\
\hline Delys & 0.8 & - & 0 & 0 & & MADE \\
\hline Yaya & - & - & 0 & 0 & & \\
\hline Samba & - & - & 0 & 0 & & \\
\hline Fili-Yoro & - & - & 0 & 0 & & \\
\hline Sounkourou & - & - & 0 & 0 & & \\
\hline Koufara & 4 & - & 0 & 0 & & Syndicat \\
\hline Kobato & 17 & - & 0 & 0 & & $\begin{array}{l}\text { DFMG, SELCO, SONAREM, } \\
\text { BRGM, Syndicat }\end{array}$ \\
\hline Toromaya & 10 & 200 & 0 & 0 & & DFMG, SELCO, BRGM, Syndicat \\
\hline Maniaguinti & 3.5 & - & 0 & 0 & & Syndicat \\
\hline Dabora & 3 & - & 0 & 0 & & SELCO, Syndicat \\
\hline Pipe 47 & 1 & - & 0 & 0 & & Syndicat \\
\hline Kenieba & 0.3 & - & 0 & 0 & & SELCO, BRGM, Syndicat \\
\hline Pipe 49 & 0.75 & - & 0 & 0 & & Syndicat \\
\hline Silifoundou & 0.7 & - & 0 & 0 & & SELCO, BRGM, Syndicat \\
\hline Fanson & 0.4 & - & 0 & 0 & & SELCO, BRGM, Syndicat \\
\hline Sakola & 0.6 & - & 0 & 0 & & SELCO, BRGM, Syndicat \\
\hline North Bilali & 0.33 & 65 & 0 & 0 & & SELCO, BRGM, Syndicat \\
\hline
\end{tabular}




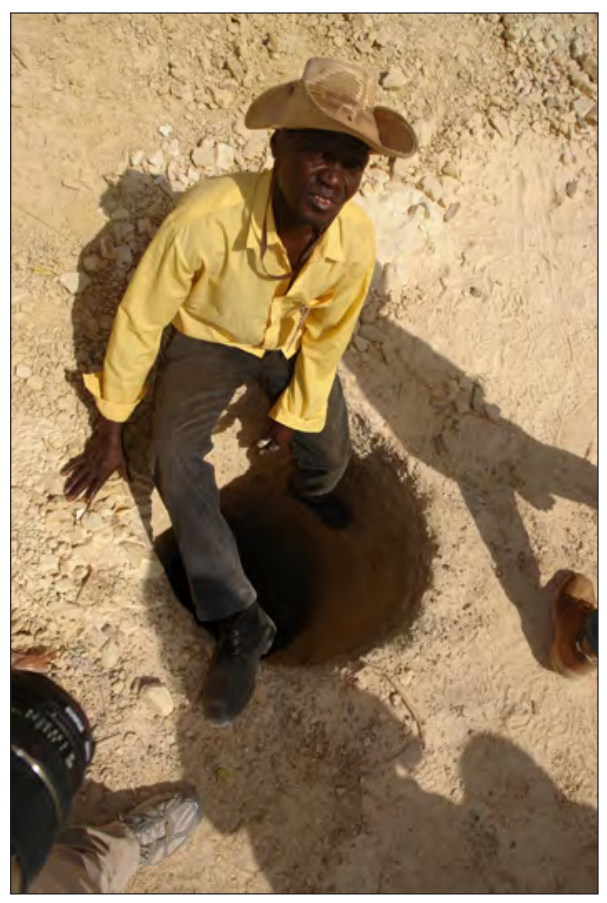

Typical artisanal mining shaft, Moralia, Mali, February 2007

In 1979, the Syndicat Diamant de Mali (Syndicat) began a large campaign of exploration that continued through 1983. Alluvial and eluvial prospecting, magnetometry, and other types of geophysical techniques were used to discover new kimberlitic bodies (Bureau de Recherches Géologiques et Minières, 1983).

It is important to note that this part of the craton is mineralized with diamonds, from the west of Guinea to north of Burkina Faso. An examination of a map of diamond occurrences suggests that the known kimberlites may be insufficient for explaining the vast extension of these signs of diamonds. Therefore, it is possible that more primary centers of dispersion exist, in addition to those that have already been discovered. Based on geology, the Adrar des Iforas and the Sikasso region may also have diamond potential (Direction Nationale de la Géologie et des Mines, 1987).

\section{Kimberlitic Age}

Though recent dating of kimberlites is not available, the cross-cutting relations of the kimberlites and dolerites provides additional information. The Kobato pipe, situated on the plateau, is crossed by a dolerite dike. The situation is the same for the North Bilali pipe. Therefore, at least these two pipes predate the doleritic intrusions, which at the very least are speculated to be Middle or Late Cretaceous in age. It is even possible that those of an older age (Pan-African) may be discovered. However, in the absence of further evidence, an Early Cretaceous age for the kimberlites is possible, although they are commonly considered to be Early Proterozoic.

\section{Surficial Morphology of the Kimberlites}

In area, the pipes vary from 8 to 20 hectares (ha). With the exception of Sakola, the cross sections are consistently rounded or kidney shaped. The Cirque pipes together cover $700 \mathrm{~m}$ and narrow to $250 \mathrm{~m}$ in diameter in the center. The Kobato pipe has a circular section close to $500 \mathrm{~m}$ in diameter. Pipe 117 has an elongated form and arcs across nearly $600 \mathrm{~m}$, which may indicate a connection with the two smaller neighboring bodies of Kenieba and Mission. The kimberlite pipes are summarized in table 1 .

\section{Alluvial Diamond Deposits}

Alluvial diamonds have been found over a very large area in Mali. Many diamonds have been discovered in river drainages that do not drain areas containing known kimberlites. Most alluvial diamonds have been found in alluvial deposits close to the Tambaoura Escarpment in the Kenieba zone (Direction Nationale de la Géologie et des Mines, 1987). Numerous discoveries have been mentioned in the alluvial sediments in the Yanifolia area of southern Mali, without the identification of a primary source. All the discoveries have been made by artisanal gold washers, even though the gravimetric techniques that they use are not optimal for the recovery of diamonds.

Currently, the only extractive activity taking place in the diamond fields is artisanal and is focused on the ancient alluvial deposits that are being exploited for gold. Diamonds constitute a by-product of gold mining.

The paleo-placers represent a large-scale alluvial event. They were deposited on a paleo-topography that has not been dissected by the present drainage. This explains the absence of significant gold potential or diamondiferous ore in the recent alluvium of the Kenieba plain. The current channels are not coincident with the paleo-channels. Consequently, the paleoplacers are not limited to the sectors revealed by gold washing. Gold and diamonds may occur together, but the presence of auriferous mineralization is dependent on the distance to the primary gold occurrence. Figure 2 shows the locations of both diamonds and gold in the Birimian geology.

\section{The Diamonds}

Diamonds were never the object of exclusive exploitation in Mali, and generally several large samples were removed from the surface of kimberlites. The majority of these diamonds were found fortuitously by gold washers. A certain number, however, come from exploration carried out by companies looking for kimberlites.

The most remarkable characteristic of the Kenieba diamonds is their exceptional size: nearly 15 percent of the stones found are greater than 15 carats and represent more than 95 percent of the weight. Diamonds larger than 50 carats are common, with the maximum registered size resting at 
232.7 carats. All of these stones are of gem quality, giving them a commercial value that could reach thousands of dollars per carat. According to an earlier study by Selection Trust, three types of diamonds occur:

- Octahedron-dodecahedron combinations, with the octahedron sides rarely perfect and having undulated ridges

- Irregular forms with curved sides that are slightly frosted

- Dodecahedrons

\section{Methodology for Assessing Mali Diamond Resource Potential}

The objective of this study was twofold. The first goal was to assess the naturally occurring endowment of diamonds in Mali, which is termed the "potential diamond resources," on the basis of geologic evidence, previous studies, and recent field data. The second goal was to assess the diamondproduction capacity through a study of current resourcedevelopment conditions in Mali and to measure the intensity of mining activity. A degree of independent analysis is reached by assessing both the potential resources and the production capacity and comparing these data with the known diamond production figures from Mali.

Several possible methods can be used to estimate the potential diamond resource. However, there is a lack of sufficient data recording all diamond mining in Mali, since diamond mining is secondary to alluvial gold production. In addition, there is a lack of consistent data for alluvial gold mining. Because time to conduct fieldwork and accessibility to the diamond mining areas are limited, four different methodologies were used in this study to assess the diamond potential: cylindrical calculation of the primary kimberlite deposits, surface area methodology, the volume and grade approach, and the content per kilometer approach. The results of these methods were cross-checked with one another to help provide clarification and redundancy in error checking.

\section{Field Data Collection and Basic Research}

An extensive search for literature on the geology and diamond mining of Mali was performed under the scope of this study. The purpose behind completing a bibliographic research study was to determine the extent of data that have already been collected and that may prove useful in the development of diamond mining assessments and general geologic background. Information on primary diamond deposits (kimberlites), alluvial diamond and gold mining sites, techniques, grades of diamond workings, and the history of diamond occurrences was extracted from many different publications and developed into a database of all diamond showings. The database was then used to extract key parameters for both the Kenieba and Bougouni alluvial mining zones. These parameters populate the tables presented in this study.

Data collected during the field campaigns in Mali provided valuable information on the number of artisans and diamond diggers operating in the country. Information about the productivity of alluvial workings and the amount of overburden at specific sites was also measured and recorded. Site visits revealed the nature of the alluvial deposit, the thickness of the gravel layers being mined, and the geomorphologic deposit types. To accurately gather the information from the field, a comprehensive questionnaire was developed and used.

Each field team was provided a set of questionnaire booklets. The booklets contained blank forms that the field teams filled out at every site that was visited during the field study. It was important to record accurately the spatial location (longitude and latitude) of the mine sites, as well as the mine conditions. Mine conditions may have included the size and depth of the mine, the distance from the closest river, town, and road, the depth of the overburden, and the thickness of the gravel. In addition, questions were asked regarding the flow of production, number of miners and teams, and additional jobs noted in the surrounding areas. Using a standardized questionnaire ensured that consistent data were gathered at each site, even though the teams were working separately at different sites and at different times throughout the country. The field data gathered through this method were incorporated into the database of alluvial diamond occurrences.

A map database of known kimberlitic occurrences, alluvial gold and diamond diggings, mine sites, and diamond recoveries was used to develop the current active mining diamondiferous deposit zones within the Kenieba and the Bougouni regions in Mali (fig. 2). The map database was derived from the database of alluvial diamond and gold occurrences and from the field data collected in this study.

Due to the limited amount of available data concerning primary diamondiferous sources, correlated with localized mining exploration, an estimate of primary diamondiferous potential cannot be made except on known kimberlitic sites where sufficient data are available.

\section{Surveyed Zones and Mining Activity}

Thirty-four sites in the Kenieba zone were visited, described in the database, and transmitted and integrated to a GIS. Twenty of them involved alluvial exploitations, while the others involved primary gold bodies. The discovery of diamonds was reported in 10 sites, half of the inventoried alluvial occurrences. The perimeter of the plateau was not inventoried, as no notable artisanal activity was reported there.

Artisanal activity first developed in the ancient alluvials (paleo-placers), which were regionally exploited for gold, and to a lesser extent in the recent alluvials of the Falémé River, which constitutes the border with Senegal. No exploitation for primary diamonds has been observed despite the existence of more than 20 kimberlitic bodies. 
It is important to take into account the fact that the paleoplacers are not limited to sectors discovered by gold washing. The zone of interest for diamonds may extend toward the north or south even though information on these zones is not available.

The thickness of these largely exploited alluvial deposits can sometimes reach $2 \mathrm{~m}$, though the level which interests the gold washers and diamond diggers does not generally exceed $0.5 \mathrm{~m}$. This zone of interest is split in equal parts between the upper part of the affected bedrock and the coarser layers that rest immediately below. The mineralized gravel is made up of sandstone, quartzite, dolerite, Neoproterozoic conglomerate pebbles, and vein quartz pebbles. The relative proportion of different sources of gravel supply is variable. For example, the pebbles of Neoproterozoic conglomerates can represent more than 50 percent of the gravel of the south (Dabiya zone) yet are limited to less than 5 percent of the gravels farther north.

The exploitation methods have remained unchanged for decades. After a hole is dug (pits are generally $0.8 \mathrm{~m}$ in diameter), the mineralized layer is excavated from pits in a radius of 2.5 to $3 \mathrm{~m}$. The activity remains familial even though the active population can travel distances of up to $60 \mathrm{~km}$. The discovery of auriferous primary rock at Moralia (quartz to visible gold), where close to 1,000 people worked at the time of February-March fieldwork in 2007, saw the temporary influx of close to 200 people to the village of Moralia, located $15 \mathrm{~km}$ north of Kenieba and $3 \mathrm{~km}$ northwest of the Tabakoto gold mine.

The estimated number of active artisans in the zone takes into account the seasonal observations made, completed, and tallied by other sources of information, such as contact with artisanal cooperatives or previous estimates made within the DNGM. A workforce of 4,000 artisans was kept for the Kenieba zone. The period of activity of 200 days takes into account a dual activity: mineral extraction and agriculture.

In Bougouni, three zones of diamondiferous potential were located, amounting to a surface area of 17,878 square kilometers $\left(\mathrm{km}^{2}\right)$. Twenty-four sites of artisanal exploration were inventoried, 21 of which were alluvial sites. The recovery of diamonds was reported in 17 of these. On-the-ground surveys allowed for the confirmation of diamond extraction in the zone. The diamonds were retrieved during the exploitation for gold in the ancient alluvials of the sector's two principal rivers, the Ouassoulou-Balé and the Sankarani, as well as in secondary streams, which can reach $1 \mathrm{~km}$ in length and more than $100 \mathrm{~m}$ in width, with "auro-diamondiferous" volumes of gravel that can reach $1.5 \mathrm{~m}$.

The exploitation is methodical but can be spread out over several years. Pits $0.7 \mathrm{~m}$ in diameter are dug, and $15 \times 2 \mathrm{~m}$ of mesh are used to extract the gravel from the pits. Despite the use of this excavation technique for distances of over $5 \mathrm{~m}$, few accidents were reported. Problems of water seepage are common in pits that have been dug into the water table, and the use of automated pumps was reported. The washing generally takes place on a calabash. No amalgamation of gold or mercury is practiced.

\section{Assessments of Diamond Potential}

Two regions of Mali were assessed for diamond potential. The first region is the Kenieba region, lying in the western portion of Mali along its border with Senegal (fig. 3). The second is the Bougouni region located south of Bamako near the border with Guinea and Côte d'Ivoire (fig. 4).

A total of four different methodologies were used in the two regions to assess potential diamond endowment. The first methodology is a cylindrical calculation of the primary diamond deposits of the known diamondiferous kimberlites. This methodology is used only in the Kenieba region, where kimberlites are known to exist. The second methodology is the surface area method, which estimates the alluvial diamonds that are known to have been eroded and deposited across a large generally uniform alluvial plain. Again, this methodology is used only in the Kenieba region and only for the portion of the region that lies west of the Tambaoura Escarpment. The third methodology is the volume and grade approach, which estimates a volume of alluvial material along stream and river courses in a defined diamondiferous deposit zone and then assigns a diamond ore grade for each cubic meter of alluvium within the zone. The volume and grade approach is used for the upland plateau area in the Kenieba region as well as the three zones defined in the Bougouni region. The fourth and final assessment methodology is the content per kilometer approach, which calculates the total length of streams and river courses within a defined diamondiferous zone and then estimates the number of carats per kilometer based on observed statistics of diamond yields along the courses of the water course. In this approach, the river reaches are classified by their richness; the highest grade streams are termed "very rich," the next well endowed streams are classified as "rich," and the least well endowed are termed "poor." For each category of stream, a number of carats per kilometer is assessed. The following sections describe the four methods for the assessment in more detail.

\section{Cylindrical Calculation of Primary Diamond Deposits}

The first approach that is used to assess Mali's potential diamond resources is the cylindrical calculation of the primary kimberlitic deposits. In this method, the surface area of the known diamondiferous kimberlite deposits is calculated from the diameter of the surface expression of the kimberlite, which has been measured and recorded. Next, the amount of erosion, estimated to be $500 \mathrm{~m}$ since the emergence of the kimberlites, is used to calculate the volume of diamonds that each kimberlite deposit has produced. Once calculated, the volume is converted into metric tonnes by multiplying the cubic meters by 2.40 and thus yielding the total weight of material in tonnes. To calculate the amount of carats distributed from the original host rock of the kimberlite, the previously measured and recorded grade in carats per tonne is multiplied by the 
total calculated tonnes. The final product of the assessment is a total carats per kimberlite assessed to have been eroded and distributed throughout the Kenieba alluvial plain and plateau.

\section{Surface Area Methodology}

The surface area methodology is used to calculate the alluvial diamond deposit endowment for a generally uniform depositional plain. This methodology is used in the alluvial plain and plateau in the Kenieba region. A GIS is used to measure the total surface area of the surfaces being assessed. In this case, there is one measurement for the Kenieba alluvial plain and a second measurement for the Kenieba plateau above the Tambaoura Escarpment. The entire surface is not considered to have gravel deposits that are diamondiferous. Rather, only 2 percent of the entire measured surfaces is estimated to have diamondiferous gravels. In both cases, the diamondiferous gravel layer is calculated to be 30 centimeters (cm) thick. The total volume of diamondiferous gravel is calculated by multiplying the $30-\mathrm{cm}$ thickness by the 2 percent of the total surface area. Of the total volume of diamondiferous gravel, 75 percent is assessed to be mineralized by a "basic grade" of diamonds per cubic meter. The remaining 25 percent is assessed as having been mineralized at a "concentration grade." The basic grade gravel volume is multiplied by the "basic grade," which, in Kenieba, is 0.01 carats per cubic meter $\left(\mathrm{kt} / \mathrm{m}^{3}\right)$. The "concentration grade" volume is multiplied by $0.10 \mathrm{kt} / \mathrm{m}^{3}$. The product of these multiplications yields a total number of carats estimated to have been deposited within the alluvial sediments of the Kenieba alluvial plain and plateau.

\section{Volume and Grade Approach}

The volume and grade approach estimates a volume of alluvial material for each stream of a particular stream order and assigns a diamond ore grade for each cubic meter of alluvium. For this method, historical data were collected on the diamond grades, excavations, and yields for each of the diamondiferous zones. A digital elevation model (DEM) was used to derive the streams and rivers and overall map database of the hydrologic drainage system of the region. The linear length values of the drainage network were measured using a GIS.

The volume and grade methodological approach can be described mathematically as:

$$
P=(V \times T 1)+(1 / 4 V \times T 2),
$$

where

$$
\begin{aligned}
& P \quad \text { is the estimated diamond resource potential, } \\
& \quad \text { and } \\
& V \quad \text { is the volume of alluvium. }
\end{aligned}
$$

The volume of alluvium is determined, in this method, by estimating the width of the alluvial flat deposit and multiplying it by the thickness of the gravel layer being mined. The product of this multiplication yields a number equal to the volume of diamondiferous gravel. Alluvial flat widths are determined by assigning a width based on the order of the river or stream.

Stream ordering is a process whereby a river system channel network map is analyzed quantitatively. The smallest tributaries in the uppermost portions of watershed are assigned an order of one. They are the smallest and shortest segments of the riverine network. When two first-order streams come together, a second-order stream is formed. Only when two second-order streams join is a third-order stream formed. This analysis continues until all streams and river channels in the network have been classified. The logic behind the stream ordering system developed by Strahler (1964) is based on the idea that order number is directly proportional to the size of the contributing watershed, to channel dimensions, and to stream discharge measurements for each stream segment.

Following this logic, the widths of the alluvial flats along stream segments of the same order will be proportional. The flat widths have been determined by previous studies (Barthélémy and others, 2006) and secondarily verified and modified by field observations. Table 2 demonstrates how each stream is assigned an alluvial width based on its order.

For each alluvial flat width there is also a corresponding measurement of the thickness of the gravel layer within the alluvial deposit that is known to be diamondiferous. Again, the values of the gravel thickness are modeled from previous studies in Mali and are based on recent field observations. The thickness of gravel layers corresponds to the order of the streams because larger, higher order streams have a greater depositional history and have been verified in the field to have larger and thicker gravel deposits.

However, the gravel layers are not all equally endowed with the same content of diamonds. Different gravel deposits within the alluvial flats may have higher concentrations based on depositional history, the type of fluvial environment present, and the time period when the alluvial gravels were

Table 2. Strahler (1964) stream order and corresponding alluvial flat widths.

\begin{tabular}{ccc}
\hline $\begin{array}{c}\text { Strahler } \\
\text { stream order }\end{array}$ & $\begin{array}{c}\text { Width of alluvial flat } \\
\text { (meters) }\end{array}$ & $\begin{array}{c}\text { Thickness of } \\
\text { diamondiferous } \\
\text { gravel layer } \\
\text { (meters) }\end{array}$ \\
\hline 1 & 5 & 0.15 \\
2 & 10 & 0.20 \\
3 & 20 & 0.30 \\
4 & 30 & 0.40 \\
5 & 40 & 0.50 \\
6 & 50 & 0.60 \\
7 & 70 & 0.80 \\
8 & 100 & 1.00 \\
\hline
\end{tabular}


originally deposited. To account for these variations in depositional history, two gravel grades are used in the formula. One grade is described as the "basic" grade and is applied to all of the alluvial gravels calculated for the volume. The second grade is the "concentration" grade. This value is applied only to one-fourth of the total calculated volume of alluvial gravel in the deposit.

T1 corresponds to the "basic" grade and is applied to the entire volume of the alluvial flat. The basic grades are determined from previous field observations listed in the tables according to the study area. Either they are determined as an average of field sampling results or they are a weighted average.

$T 2$ corresponds to the "concentration" grade of the alluvial gravels. This grade accounts for the fact that diamond occurrences are not uniformly consistent throughout the entire deposit. In addition, previous studies have determined that artisanal miners are unlikely to work gravels where the grade is less than 0.1 to $0.2 \mathrm{kt} / \mathrm{m}^{3}$ (Barthélémy and others, 2006). There are exceptions to this, where artisanal miners may dig in the hope of finding a rare but single large stone in an otherwise very low-grade deposit and also where the recovery of diamonds is not the primary goal of the artisanal miners. In Mali, the basic grades are as low as $0.01 \mathrm{kt} / \mathrm{m}^{3}$ because diamond mining is incidental to artisanal gold mining. Therefore, miners are not specifically mining for diamonds, nor are their mining equipment and practices well suited to diamond recovery. The concentration grade in Mali is estimated to be $0.10 \mathrm{kt} / \mathrm{m}^{3}$ in the Kenieba region and $0.05 \mathrm{kt} / \mathrm{m}^{3}$ in the Bougouni region.

\section{Content per Kilometer Approach}

Bardet (1974) proposed another possible approach to determining the potential diamond resources of Mali's alluvial deposits, which was to assess the grade of the diamond resources as a function of the amount of carats recovered per kilometer of length of the stream or river along which they are recovered. His studies classified rivers and streams as being in one of three general categories: very rich, rich, or poor. Bardet assigned ranges of values of grades from 400 carats per kilometer $(\mathrm{kt} / \mathrm{km})$ to $10,000 \mathrm{kt} / \mathrm{km}$ to each of the categories. The fieldwork conducted by the team determined categories of diamondiferous content per kilometer for rivers, which are presented in table 3. Similar to the technique presented in the

Table 3. Diamond yield per kilometer of stream length, Mali.

[values are in carats per kilometer]

\begin{tabular}{cccc}
\hline Zone & $\begin{array}{c}\text { T1- } \\
\text { Very rich } \\
\text { streams }\end{array}$ & $\begin{array}{c}\text { T2- } \\
\text { Rich } \\
\text { streams }\end{array}$ & $\begin{array}{c}\text { T3- } \\
\text { Poor } \\
\text { streams }\end{array}$ \\
\hline Kenieba & 750.00 & 250.00 & 80.00 \\
Bougouni & 350.00 & 120.00 & 40.00 \\
\hline
\end{tabular}

volume and grade approach, historical data were collected on the diamond grades, excavations, and yields for each of the diamondiferous zones. The same derived stream and river hydrologic drainage system of the country was used to calculate the necessary stream lengths and orders. The calculation of linear length values of the drainage network were measured using a GIS.

Following this categorization, this study used a modified version of Bardet's approach, which can be expressed by the formula

$$
\begin{gathered}
\mathrm{R}_{\text {total }}=(L 1 \times T 1)+(L 2 \times T 2)+(L 3 \times T 3), \\
\text { and where } \mathrm{R}_{\text {concentrated }}=(V 2 \times T 2)+(V 3 \times T 3)
\end{gathered}
$$

Each contoured zone is assigned an average diamond grade per kilometer of stream length. These grades correspond to $T 1$ for very rich, $T 2$ for rich, and $T 3$ for poor. The total length of streams within each study area is calculated. The total length of streams that falls into each of the categories (very rich, rich, and poor) is then calculated from the total and assigned to each of the $L 1, L 2$, and $L 3$ variables. Using these two parameters, the cumulative length of streams within each of the three categories of stream endowments is developed. The cumulative length of streams within each category is then multiplied by the number of carats per kilometer for that type of stream. The result of the multiplication is a total estimated amount of carats for each stream endowment type for each study area. The total carats per kilometer are summed for each study area, which then provides a total estimated endowment for each study area.

\section{Methodology to Estimate the Capacity of Mali's Diamond Production}

Diamond-production capacity is defined as the current volume of diamonds (calculated as total number of carats) that can be produced utilizing current human and physical resources. The estimate of diamond-production capacity does not reflect the possibility of future introduction of new financial capital investment or improved exploration or mining techniques, nor does it model increases of human resources (labor capital) in the mining sector. Rather, it is a measure of the current state of the diamond mining sector based on recent field data collected and on previous research studies of diamond mining, gravel grades, and estimates of the total number of alluvial diamond diggers and small mining cooperatives. To assess the diamond-production capacity, a formulaic model was developed. It can be stated mathematically as:

$$
P_{i}=(V m / j \times t) \times j \times A_{i}
$$


where

$$
\begin{aligned}
& P_{i} \quad \text { is the total current production capacity, } \\
& \mathrm{Vm} / \mathrm{j} \quad \text { is the volume of material worked for each } \\
& \text { digger per day, } \\
& t \text { is the average gravel grade, } \\
& j \quad \text { is the total number of days that a digger works } \\
& \text { per year, and } \\
& A_{i} \quad \text { is the total number of diggers. }
\end{aligned}
$$

The grade $(g)$ parameter used for the evaluation is the mean value of the Kenieba and Bougouni zones, which is $0.05 \mathrm{kt} / \mathrm{m}^{3}$. Human mining activity $(\mathrm{Vm} / \mathrm{j})$ is calculated to be 0.1 cubic meter $\left(\mathrm{m}^{3}\right)$ per miner per day and takes into account the highly variable situations given the nature of the alluvial gold deposits and also incorporates the overall stripping ratio range of approximately from 0 to 40:1 for the deposits. The total number of days $(j)$ worked is estimated to be 200 days a year and takes into account inaccessibility of many of the deposits during the rainy season and the variability of agricultural pursuits for many of the miners. The total number of diggers estimated during reconnaissance fieldwork $\left(A_{i}\right)$ was 4,000 in Kenieba and 2,000 in Bougouni.

\section{Results}

\section{Cylindrical Calculation of Primary Diamond Deposits}

The three diamondiferous kimberlites in the Kenieba region are North and South Cirque, South Bilali, and Orange River. Utilizing historical records of diamond sampling for the grades of these kimberlites, a series of calculations was performed. The calculations show the surface area and estimated volume of eroded and distributed diamonds that are estimated to have been liberated from the original host rock. Table 4 shows the results of the calculations and further demonstrates that North and South Cirque are estimated to have distributed approximately 465,000 carats, whereas South Bilali and Orange River have yielded 116,000 and 1,800 carats, respectively. These diamonds are assessed as remaining in the alluvial materials of the Kenieba alluvial plain and plateau.

\section{Surface Area Methodology}

The surface of Kenieba's alluvial plain and the Tambaoura plateau is estimated to be the secondary host to diamonds eroded from the primary kimberlite deposits. The surface area methodology was used to assess the number of diamonds that are thought to be remaining in the alluvial sediments of each of these areas. For the plain and plateau, a series of surface areas, volumes, and a final volume of diamonds is presented in table 5. The alluvial plain is calculated to be the host of approximately 18,760,540 carats of diamonds, using the surface area method. A total of 4,690,135 carats is calculated to be in concentration grade deposits within the alluvial plain. The Tambaoura plateau is estimated to host approximately 3,525,067 carats with 881,266 carats deposited in concentration grade alluvial gravels. The total amount of carats thought to be deposited in the Kenieba region is estimated to be approximately 700,000, with just over 550,000 located in concentration grade deposits.

\section{Volume and Grade}

The results of the volume and grade methodological assessment are presented for each diamond deposit zone identified in the mapping. Table 6 presents results for the Kenieba region zone, and table 7 presents results for the Bougouni region.

Table 4. Primary kimberlite diamond resources, Kenieba, Mali.

\begin{tabular}{lrrr}
\hline & North and South Cirque & South Bilali & Orange River \\
\hline Diameter of kimberlite surface (meters) & $61,124.11$ & $13,784.76$ & $15,917.71$ \\
Surface area of kimberlite (square meters) & $192,026.89$ & $43,306.06$ & $50,006.92$ \\
Calculated depth of erosion (meters) & 500.00 & 500.00 & 500.00 \\
Total volume of eroded kimberlite (cubic meters) & $96,013,446.37$ & $21,653,032.08$ & $25,003,459.28$ \\
Conversion factor for cubic meters to metric tonnes & 2.40 & 2.40 & 2.40 \\
Total weight (tonnes) & $230,432,271.28$ & $51,967,277.00$ & $60,008,302.27$ \\
Divided by 1,000 tonnes & $230,432.27$ & $51,967.28$ & $60,008.30$ \\
Calculated carats per 1,000 tonnes & 2.02 & 2.24 & 0.03 \\
Total estimated resource (carats) & $\mathbf{4 6 5 , 4 7 3 . 1 9}$ & $\mathbf{1 1 6 , 4 0 6 . 7 0}$ & $\mathbf{1 , 8 0 0 . 2 5}$ \\
Total & & & $\mathbf{5 8 3 , 6 8 0 . 1 4}$ \\
\hline
\end{tabular}



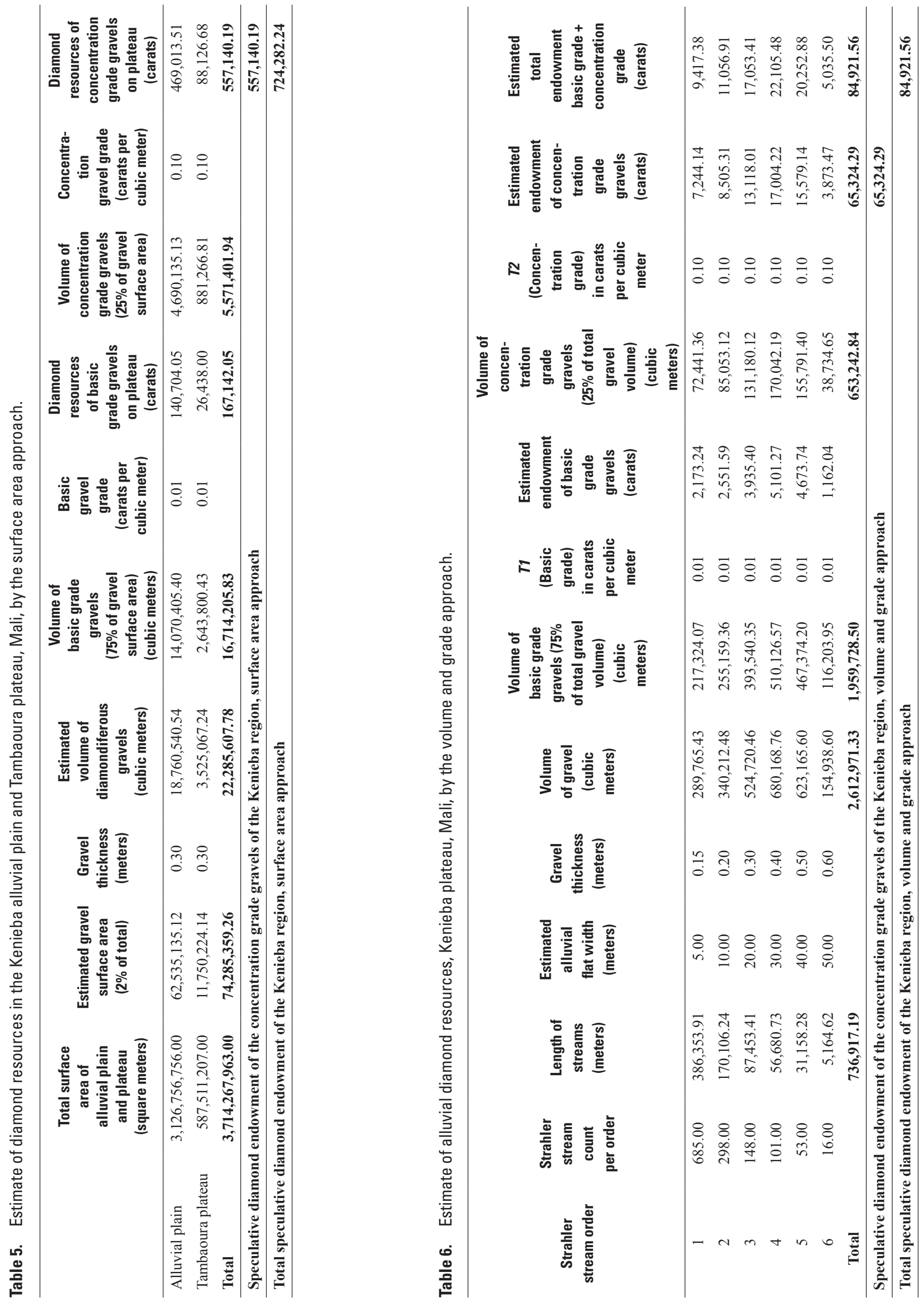


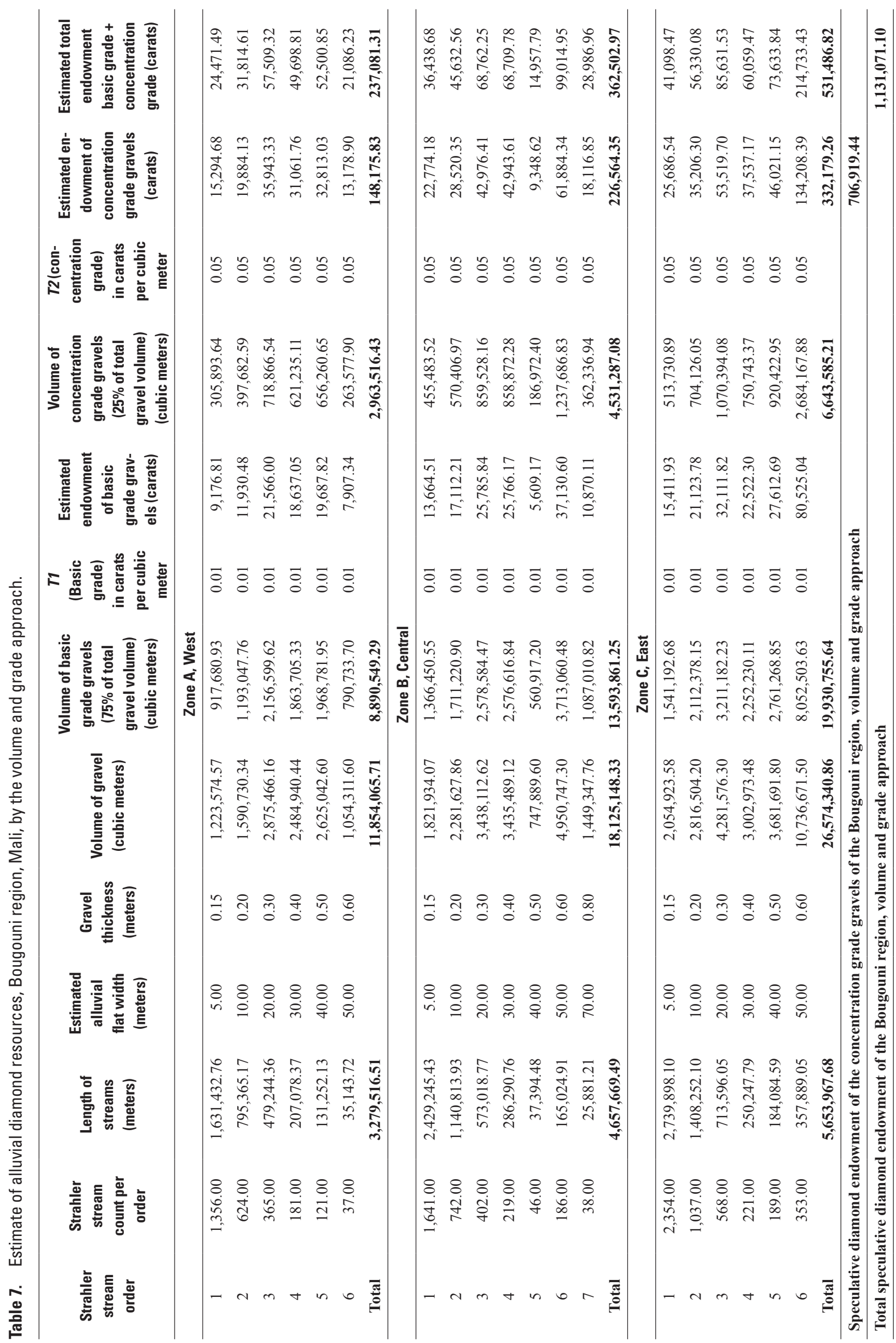




\section{Kenieba Region Plateau}

Table 6 gives the results of the Kenieba plateau assessed through the volume and grade methodology. The table gives the total length in kilometers for all streams and rivers in the study area. Estimated alluvial flat widths and gravel thicknesses are given in table 6 and also correspond to the stream ordering method as described in table 2 . The total lengths for each stream order are multiplied by the corresponding alluvial flat and gravel thickness measures, yielding the total volume of diamondiferous gravel. The total volume of "basic" grade gravels is calculated from the total by dividing it by threefourths. For the basic gravels of the Kenieba region, a grade of $0.01 \mathrm{kt} / \mathrm{m}^{3}$ is applied, which then results in the estimated endowment of the basic grade gravels for that zone.

For each contoured zone, the volume of "concentration" grade gravels is calculated as one-fourth of the total alluvium of the zone. The concentration grade (T2) of Kenieba gravels is $0.10 \mathrm{kt} / \mathrm{m}^{3}$. The estimated endowment of the concentration grade gravels is calculated by multiplying the concentration volume by the concentration grade and yields the estimated endowment of concentration grade gravels.

The total estimated endowments for each zone are then summed. The estimated endowment for concentration grade gravel deposits of the Kenieba plateau is 65,324 carats. When combined with the basic grade gravel endowments, the total estimated resource is 84,921 carats.

\section{Bougouni Region}

Three contoured zones of alluvial gold and potential diamond deposits were derived from the point location database showing the location of recorded alluvial gold diggings and workings in the Bougouni region of Mali. For each of the diamondiferous deposit zones, the calculation for volume and grade was performed. Figure 4 shows the map of the Bougouni region and the three zones evaluated in this study.

Table 7 gives the results of the volume and grade approach in the Bougouni region. The results table is divided into three sections. Each section corresponds to one of the three map zones identified. For each zone, the table section lists the Strahler ranked streams and rivers and records the total length in kilometers for each Strahler order. The total length per Strahler order is multiplied by the thickness of the gravel deposit, which yields the total volume of gravel. The total volume of "basic" grade gravels is calculated from the total alluvium by multiplying it by three-fourths. For the basic gravels of Bougouni, a grade of $0.01 \mathrm{kt} / \mathrm{m}^{3}$ is applied, which then results in the estimated endowment of the basic grade gravels for that zone.

For each contoured zone, the volume of "concentration" grade gravels is calculated as one-fourth of the total alluvium of the zone. The concentration grade (T2) of Bougouni gravels is $0.05 \mathrm{kt} / \mathrm{m}^{3}$. The estimated endowment of the concentration grade gravels is calculated by multiplying the concentration volume by the concentration grade and yields the estimated endowment of concentration grade gravels.

The total estimated endowments for each zone are then summed. The estimated endowment for concentration grade gravel deposits of Bougouni is 706,919 carats. When combined with the basic grade gravel endowments, the total estimated resource is $1,131,071$ carats.

\section{Content per Kilometer Results}

Tables 8 and 9 give the results of the content per kilometer approach for the Kenieba and Bougouni regions. The total stream lengths are derived from the GIS for the zones that are known to be diamondiferous. From the total length, percentages are derived according to the classification of the lengths into "very rich streams," "rich streams," and "poor streams." For the Kenieba region, 5 percent of the total stream length is classified as very rich, 20 percent is classified as rich, and the remaining 75 percent is classified as poor. Similarly, for the three Bougouni zones, 5 percent of the total stream length is classified as very rich, 20 percent is classified as rich, and the remaining 75 percent is classified as poor.

Each classified stream length per zone is multiplied by the estimated content per kilometer and finally summed by zone. In the Kenieba zone, very rich deposits are estimated at $750 \mathrm{kt} / \mathrm{km}$, rich deposits are estimated at $250 \mathrm{kt} / \mathrm{km}$, and poor deposits are estimated at $80 \mathrm{kt} / \mathrm{km}$. The Bougouni zone deposits are estimated to be less rich than the Kenieba deposits. Therefore, very rich deposits are estimated at $350 \mathrm{kt} / \mathrm{km}$, rich deposits are estimated at $120 \mathrm{kt} / \mathrm{km}$, and poor deposits are estimated at $40 \mathrm{kt} / \mathrm{km}$.

The total estimated deposits of the Kenieba region, according to the content per kilometer approach, are 108,695 carats. The total estimated deposits of the Bougouni zones, according to the content per kilometer approach, are 971,828 carats.

\section{Summary for Kenieba and Bougouni Diamond Potential}

Tables 10 and 11 give the results of the summary of estimated diamond resource endowment results for the Kenieba and Bougouni regions. Table 10 summarizes the three different methods used in the Kenieba region for the alluvial diamond deposits and a fourth method for the assessment of the primary kimberlitic diamond resources. The three results for the alluvial diamond resources of the Kenieba alluvial plain and plateau are averaged, developing one assessment figure from the three methods. Approximately 700,000 carats are estimated to be in the alluvial deposits in the Kenieba region, with 540,000 carats calculated to lie within the concentration grade deposits.

Additionally, 580,000 carats are estimated to have been released from the primary kimberlites in the region. Therefore the total estimated diamond resources in the Kenieba region are thought to be nearly $1,300,000$ carats. 

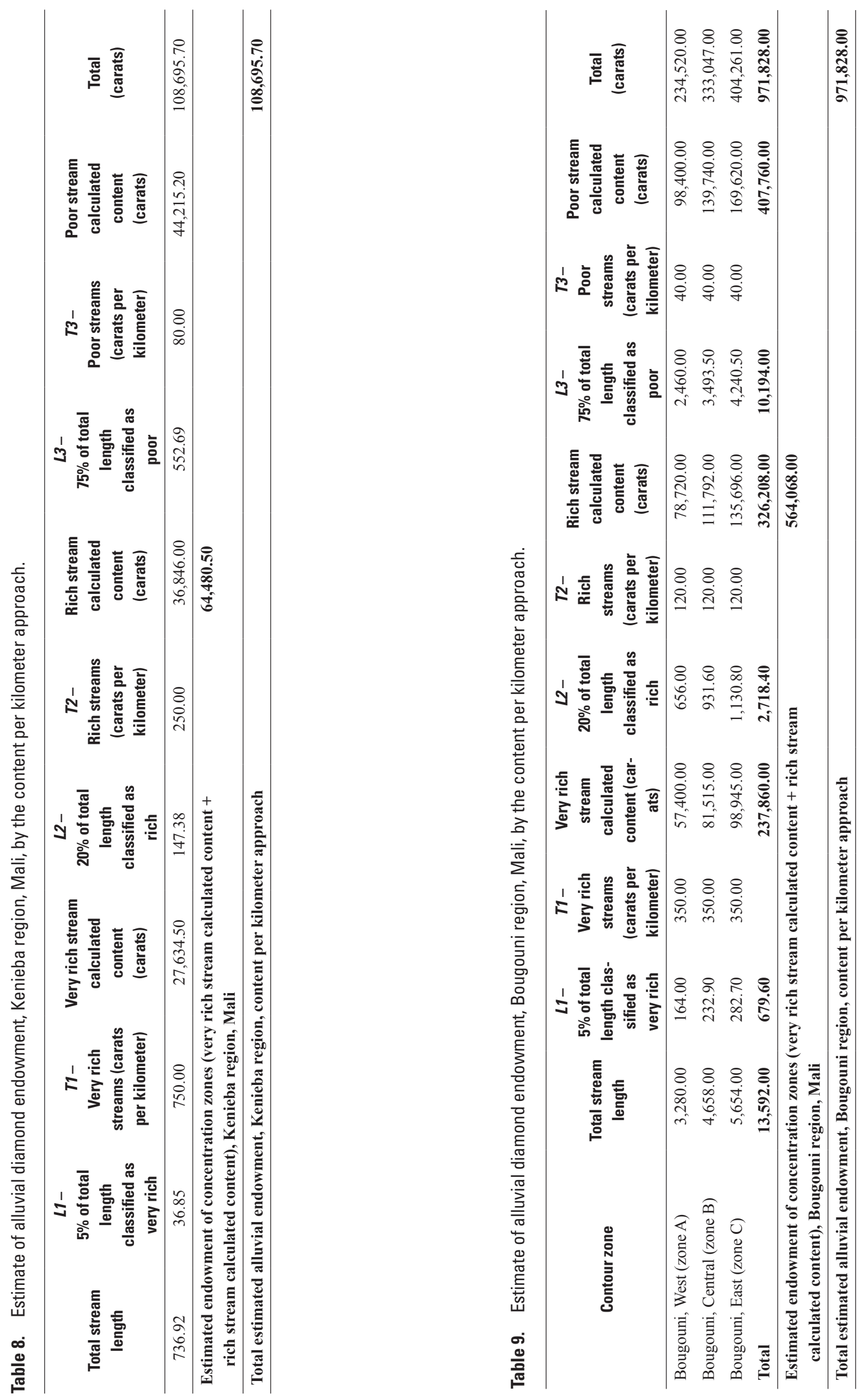

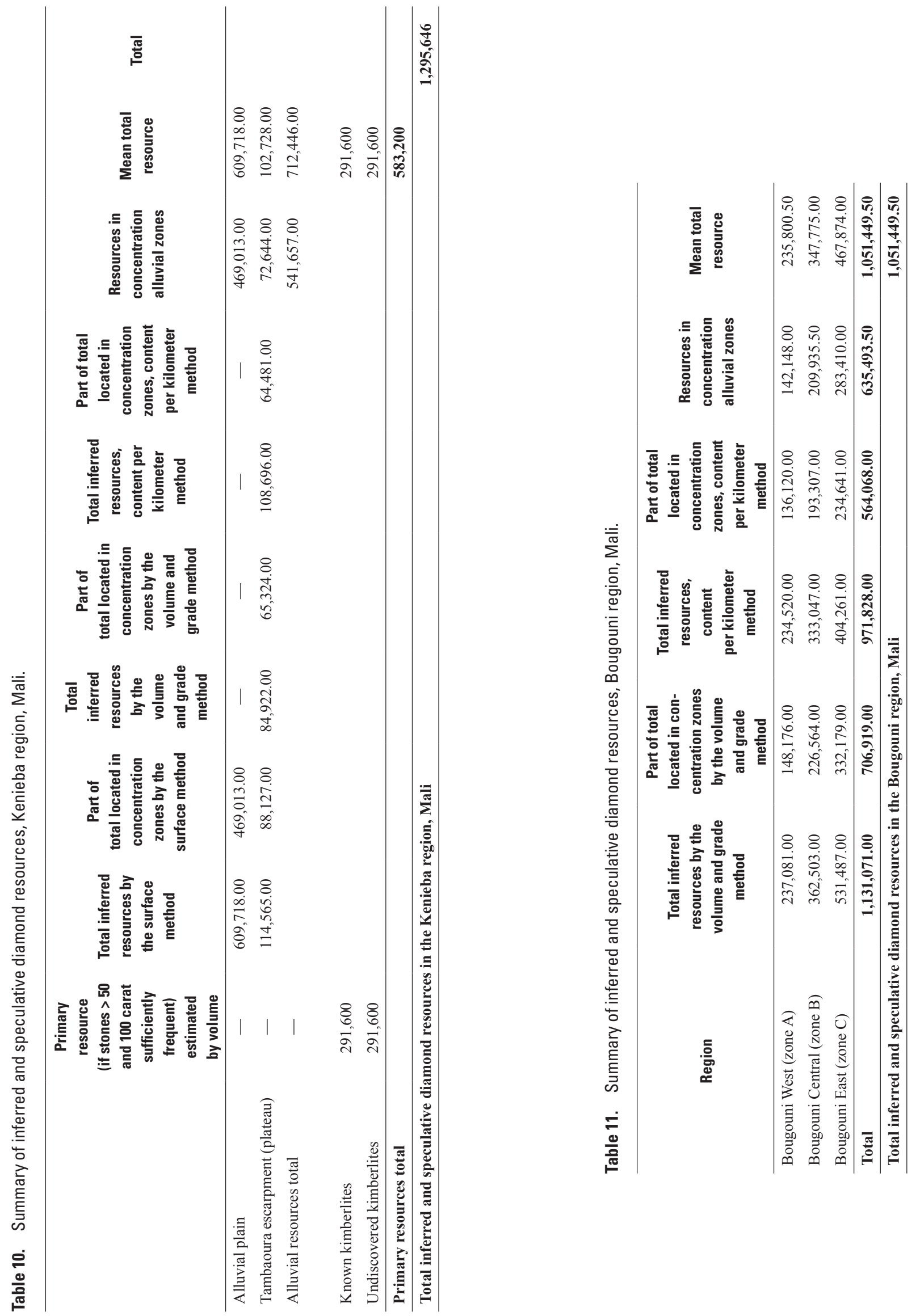
Table 11 gives the summary results of the volume and grade method and the content per kilometer method for the Bougouni zones. Similar to that of the Kenieba region, an average endowment figure was developed from the two different methodologies for Buogouni. In summary, the Bougouni zones are estimated to have $1,000,000$, carats with more than half, 630,000 carats, contained in concentration grade deposits.

When combined, the diamond endowment of Kenieba and the Bougouni regions of Mali are estimated to be host to $2,300,000$ carats of diamonds.

\section{Diamond-Production Capacity}

In Mali, it is clear from field observations and reports that diamond mining is at present a byproduct of artisanal gold digging. As such, methods currently employed in the artisanal gold mining sector are not the best practices for the recovery of diamonds. The assessment of production capacity is therefore designed to address the current situation based on field observations. Teams of artisans generally work together in groups of up to four people per team, and the activities of team members are gender related. Women were observed to transport and wash the ore, which was generally observed to have been dug by the men.

The diamond production capacity model was used to calculate the estimated production capacity of Mali. It was stated mathematically in equation 4.

Based on observations made in the field during the two field excursions, the following parameters were developed. The calculation of production capacity is given as

$$
6,000=(0.1 \times 0.05) \times 200 \times 6,000 .
$$

The results of this estimated model may be more realistically expressed as a range of values from 3,000 to 9,000 carats per year. Given the highly unpredictable nature of the artisanal sector and the understanding that the diamond recoveries are secondary to alluvial gold production, a range of values seems more consistent with the observations and data gathered in the field.

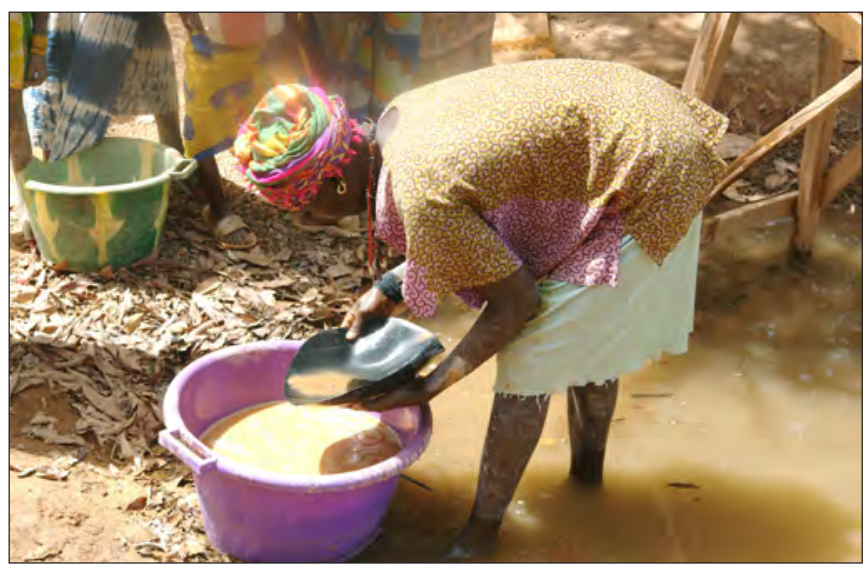

Woman panning for alluvial gold in Kenieba, Mali, February 2007

\section{Discussion}

The goal of this study was to estimate the geologic resource endowment and the production capacity of diamond resources in Mali. To achieve this goal, four methodologies were utilized to estimate the geologic resource potential of two regions in Mali known to host diamonds. An additional method was used to estimate the production capacity of the diamond mining sector based on data concerning the numbers of artisanal miners, their productivity, and the grades of the diamond deposits.

The result of the geologic resource component of this study calculated that Mali is host to approximately $2,300,000$ carats of primary and alluvial diamonds. Estimates show that 1,300,000 carats are located in the Kenieba region and that an additional 1,000,000 carats are located in the Bougouni region. Production capacity estimates show that Mali is capable of producing between 3,000 and 9,000 carats per year given the current state of mining activity and productivity.

This study relies on models of alluvial deposition and concentration of diamonds across large areas of Mali. Few previous studies have gathered detailed information on the grade and nature of specific mine sites. Therefore, a variety of theoretical methods were used in this study to predict the resource potential. Also, the alluvial diamond deposits of Mali are of low grade and are spread over large alluvial plains and valleys. Artisanal miners are more heavily invested in the alluvial gold sector than the diamond sector. Gold is the primary goal of the artisanal worker; therefore, the tools and methods employed in Mali are focused on gold and not on the recovery of diamonds.

\section{Conclusion}

Given the available data, two zones can be considered to have priority in terms of diamondiferous potential. Both are located in southwestern Mali, in the Kenieba and Bougouni regions, within the Birimian Sandstone of the West African Craton. The only known primary occurrences are situated in the Kenieba region, where 20 to 30 kimberlites have been defined. Mali's alluvial diamond resources are contained within a thin layer of ancient alluvium with a stripping ratio that can reach, in extreme cases, 40 to 1 . In all of the findings, extractive activity is exclusively artisanal, with diamonds merely constituting a byproduct of gold washing.

An estimate of the geological diamondiferous potential was undertaken in these two zones by putting into place multiple experimental methods that had previously been validated in other countries in similar contexts. The total average alluvial resources estimated by three different methods rose to $1,763,895.5$ carats, of which $1,177,150.5$ carats were in concentration zones (see tables 10 and 11). 
In the Kenieba zone where eight kimberlitic bodies were diamondiferous, the primary potential is an estimated 583,200 carats. The known kimberlites demonstrate diamond mineralization that is weak to modest but far from negligible. The tests carried out on the North and South Cirque pipes and South Bilali pipe show contents close to the order of 2 carats per 1,000 tonnes and diamonds of relatively large sizes, with close to 1.7 carats per stone for North and South Cirque and 2.2 carats per stone for South Bilali.

The Kenieba province is particularly known for having produced diamonds of relatively large sizes, from between 15 and 100 carats, with the largest being 232 carats. At the same time however, the region also produces populations of small stones. Overall, close to 15 percent of the stones are greater than 15 carats and represent more than 95 percent of the weight. The diamonds are of gem quality and have a commercial value that can, with such dimensions, reach several thousands of dollars to the carat.
This study found that content in the alluvial field was very conservative. The lack of a strong collection, combined with thin gravels, leaves little hope for developing the resource other than through artisanal activity. The task of developing these resources could be rendered more attractive if a significant portion of recovered stones appeared to be exceptional in weight and quality.

Nearly 6,000 people are currently involved in gold washing, 4,000 of which work in the Kenieba zone alone. With an involvement that does not exceed 200 days per year in the artisanal sector, the annual production capacity of diamonds is between 3,000 and 9,000 carats per year.

The prospect of discovering primary deposits remains subordinate to complementary work. In the short term, diamondiferous production will continue to subsist on artisanal activity. It is reasonable to foresee a real possibility of primary kimberlitic deposits not only in the diamondiferous zones inventoried in this study but also in zones in a favorable geostructural context such as the Adrar des Iforas.

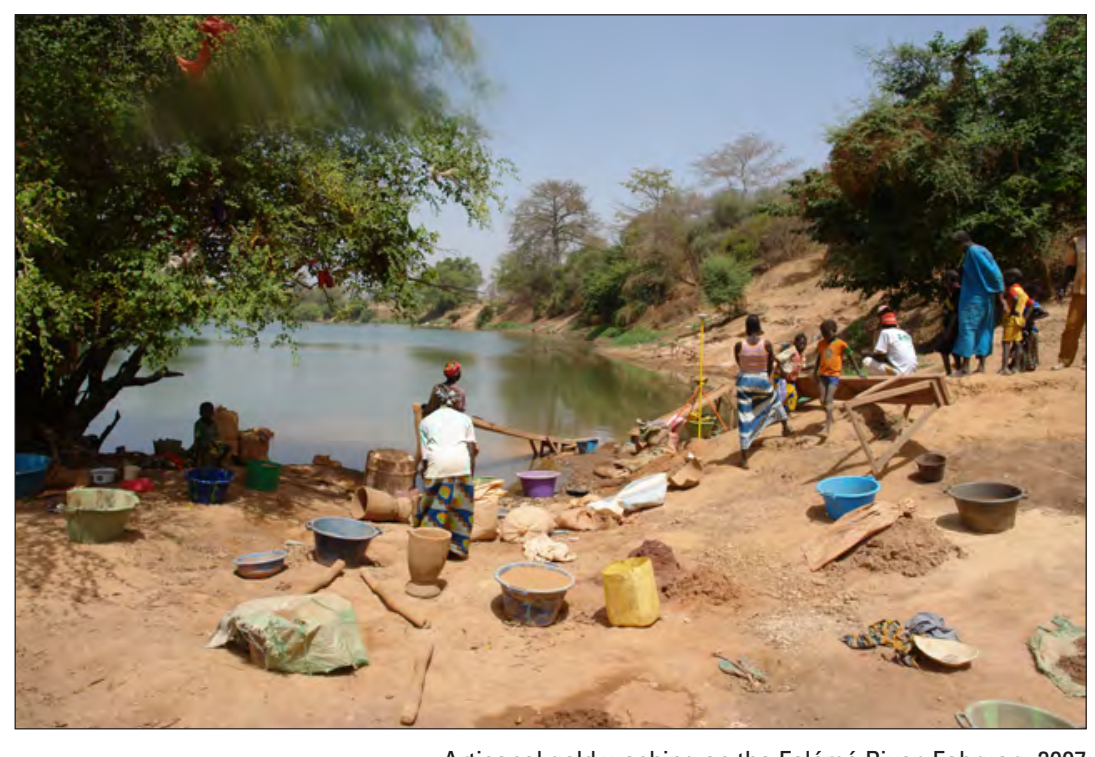

Artisanal gold washing on the Falémé River, February 2007 


\section{References Cited}

Arnold, R.R., 1991, Project evaluation report on the Kenieba diamond concession, Republic of Mali, West Africa: Mink Mineral Resources Inc., 23 p.

Bardet, M.G., 1974, Géologie du diamant, gisements de diamants d'Afrique: Bureau de Recherches Géologiques et Minières Memoir, v. 2, no. 83, 223 p.

Barthélémy, F., and others, 2006, Republic of the Congo, diamond potential, production capacity, and the Kimberley Process-Final report: Bureau de Recherches Géologiques et Minières RC-54589-EN, $99 \mathrm{p}$.

Bessoles, B., 1997, Géologie de l'Afrique, Le craton ouestafricain: Bureau de Recherches Géologiques et Minières Memoir, no. 88, 402 p.

Bureau de Recherches Géologiques et Minières (BRGM), 1983, The diamond bearing and kimberlitic province of Kenieba, Development perspectives: Orléans, France, Bureau de Recherches Géologiques et Minières, 20 p.

Direction Nationale de la Géologie et des Mines (DNGM), 1987, Mineral resources of Mali: Direction Nationale de la Géologie et des Mines, United Nations, Project UNDP/DTCD MLI/85/007.

Kusnir, I., 1999, Gold in Mali: Acta Montanistica Slovaca, v. 4, p. 311-318.

Le Billon, Philippe, 2008, Diamond wars? Conflict diamonds and geographies of resource wars: Annals of the Association of American Geographers, v. 98, no. 2, p. 345-372.
Lescuyer, J.L., and Milési, J.P., 2004, Africa GIS and SIGAfrique network-Geological and metallogenic information system, tools for sustainable development: France, 20ème Colloque de Géologie Africaine.

Michel, J.C., 1996, La province kimberlitique et diamantifère de Kéniéba, Mali: Africa Geoscience Review, v. 3, no. 2, p. 231-246.

Milési, J.P., Feybasse, J.L., Ledru, P., Dommanget, A., Ouegraogo, M.F., Marcoux, E., Prost, A., Vinchon, C., Sylvain, J.P., Johan, V., Tegyey, M., Calvez, J.Y., and Lagny, P., 1989, Les minéralisations aurifères de l'Afrique de l'ouest-Leurs relations avec l'évolution lithostructurale au Protérozoïque inférieur: Orléans, France, BRGM, accompanies Chronique de la recherche minière, no. 497, 98 p.

Olsson, Ola, 2006, Diamonds are a rebel's best friend: The World Economy, Blackwell Publishing, v. 29, no. 8, p. 1133-1150.

Schlüter, Thomas, 2006, Geological atlas of Africa, with notes on stratigraphy, tectonics, economic geology, geohazards and geosites of each country: Berlin, Springer, $272 \mathrm{p}$.

Strahler, A.N., 1964, Quantitative geomorphology of drainage basins and channel networks, in Chow, V.T., ed., Handbook of applied hydrology: McGraw-Hill, p. 4-40.

Wahl, R.R., 2007, Geologic, geophysical, and mineral localities map of Liberia-A digital compilation: U.S. Geological Survey Open-File Report 2007-1258, 2 DVDs. 
